\title{
Crouching Crossbowmen in Early Twelfth-Century Sculpture: A Nasty, Brutish, and Short(-Lived) Iconography
}

THERESE MARTIN Consejo Superior de Investigaciones Científicas, Madrid

\begin{abstract}
Around the turn of the twelfth century, a new iconography arose in northern Spanish and southern French lands. The sculpted image of a naked crossbowman, crouching to arm his weapon, flourished briefly and then vanished within a few decades. The crossbow was just coming into common usage at this time; with little training, it could be wielded by peasants or women to defeat mounted knights and thus had the potential to destabilize social structures. I analyze the display of the Romanesque crouching crossbowman to understand this heretofore unexamined iconography, investigating the reasons behind its initial conception, layered content, and rapid disappearance. Even more than the textual references to crossbows that have come down to us, I contend that visual analysis, together with an understanding of the specific historical context that encompassed the short life of this iconography, enables us to decipher the multiple meanings behind the image.
\end{abstract}

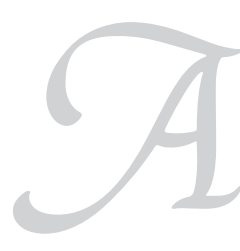

$t$ the Romanesque church of San Isidoro in León, two female figures project from the corners of a capital in the south arcade, capturing the eye of even a casual observer
(Fig. 1a). Located on the west side of the pier immediately visible to one's left after passing through the Lamb Portal, the principal entrance of the church, these naked women, in extremely high relief, at once attract and repel. They draw attention to themselves with smooth and rounded surfaces, from their widespread limbs and flowing hair to the snakes that slither between their thighs. The serpents call to mind not only the archetypal association with Eve in the Garden of Eden but also the well-known Romanesque personification of Luxuria, in which snakes latch on to the naked breasts of female figures as a punishment for lust. ${ }^{1}$ On the right side of the capital, a talon-footed demon extends an index finger to touch the snake's tongue (Fig. 1b). ${ }^{2}$ The demon's flayed appearance is juxtaposed disturbingly with the sensual nudity of the female figures, whose undulating hair highlights the smoothness of their flesh, their locks culminating in a curve that mirrors the serpents' tails. The visible musculature of the demonic creature reminds the viewer of what lies beneath the alluring surface of the women's soft skin, while his gesture of speaking or command, by its contact with the serpent's tongue, completes the diabolical connection between women and snakes.

This article is dedicated to Judith K. Golden for all her generous help, not only during my research at the Index of Christian Art but also for the encouragement she offered as my ideas about the iconography of the Romanesque crossbowman developed over the years. I offer thanks to Peter Scott Brown, Amanda Dotseth, Alexandra Gajewski, Julie Harris, Antonio Ledesma, Stefanie Seeberg, and José Luis Senra for their comments on an earlier version of this study. Special gratitude is owed to Jerrilynn Dodds for her thorough and clear-sighted critiques, and to Gesta's editors and anonymous readers for their valuable suggestions. I would also like to acknowledge the generosity of Hugh Soar, Hon. Secretary of the Society of Archer-Antiquaries, for facilitating my access to the society's journal. The research leading to these results has received funding from the European Research Council under the European Union's Seventh Framework Program (FP7/2007-2013)/ERC Starting Grant no. 263036, Reassessing the Roles of Women as “Makers” of Medieval Art and Architecture (www.mefecit.es).

1. The most familiar image is from the portal sculpture at Moissac. See Amanda Luyster, "The Femme-aux-Serpents at Moissac: Luxuria (Lust) or a Bad Mother?", in Between Magic and Religion: Interdisciplinary Studies in Ancient Mediterranean Religion and Society, ed. Sulochana R. Asirvatham, Corinne Ondine Pache, and John Watrous (Lanham, MD: Rowman \& Littlefield, 2001), 165-91. For the topic overall, see Jacqueline Leclercq-Kadaner, "De la Terre-Mère à la Luxure: à propos de La migration des symboles," Cahiers de civilisation médiévale 18, no. 69 (1975): 37-43; also Anthony Weir and James Jerman, Images of Lust: Sexual Carvings on Medieval Churches (London: Routledge, 1993), 58-79.

2. The left side of this capital is difficult to view because of the later addition of a raised choir. What can be made out is a seated male figure, clothed, shod, and cross-legged, who seems to reach out toward the woman while a snake licks her cheek. Therese Martin, Queen as King: Politics and Architectural Propaganda in Twelfth-Century Spain (Leiden: Brill, 2006), esp. 119-20.

Gesta v54n2 (Fall 2015).

0031-8248/2015/7703-0004 \$10.00. Copyright 2015 by the International Center of Medieval Art. All rights reserved. 

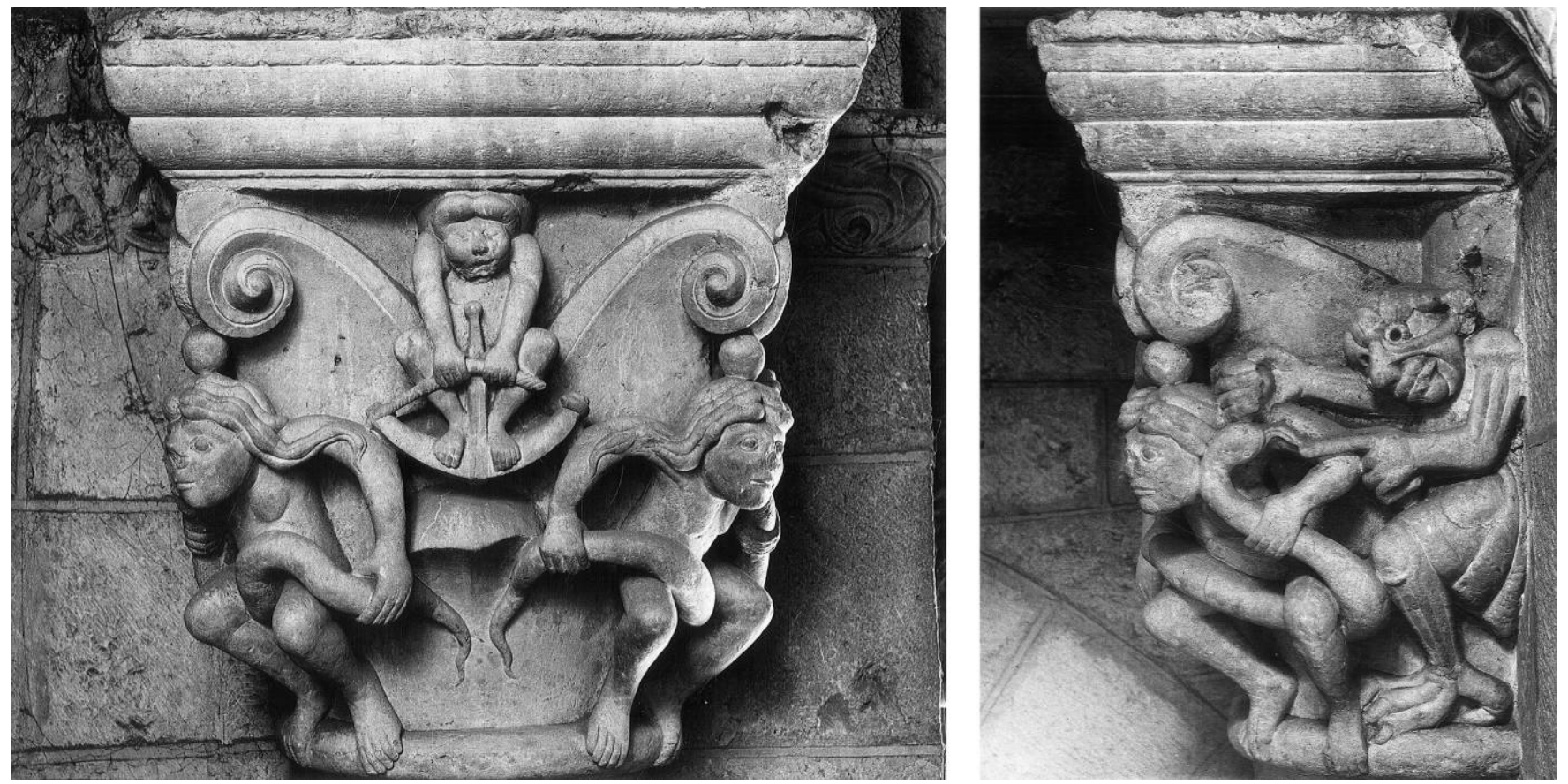

Figure 1a-b. Crouching crossbowman capital, front and right side, San Isidoro, León, first quarter of twelfth century (photos: John Williams).

To this point, the Leonese capital displays fairly unsurprising iconography for the early twelfth century, if composed and rendered with uncommon skill by its sculptor. What is not, however, normally part of the naked-woman-withsnakes topos is the smaller, squatting, nude figure centered in the upper area of the capital (Fig. 1a). ${ }^{3}$ He cocks a twofoot crossbow, the bulbous stock of which is placed in such a way that it stands in for a phallus. Just as the frontal view of a double-tailed mermaid, omnipresent in imagery now labeled Romanesque, evokes the exhibition of the vulva as she spreads her tails, ${ }^{4}$ so the frontal view of the squatting crossbowman

3. I use the terms nude and naked interchangeably to define a lack of clothing, which in this particular iconography of the crossbowman conveyed a negative meaning. The nude figure could, of course, represent innocence or purity, as in the common Romanesque image of the embodied but genderless soul raised to heaven by angels. For further discussion of positive or neutral nudity in Romanesque art, such as dead bodies in battle scenes or the Flood, see Jean Wirth, L'image à l'époque romane (Paris: Cerf, 2008), 273-303. For a recent examination of the greater implications of unclothed medieval figures, see the essays in Sherry C. M. Lindquist, ed., The Meanings of Nudity in Medieval Art (Farnham: Ashgate, 2012), esp. the introduction by Lindquist and the epilogue by Madeline H. Caviness. The classic study is Kenneth Clark, The Nude: A Study in Ideal Form (New York: Pantheon, 1956).

4. Wirth, L'image à l'époque romane, 170. At Perrecy-les-Forges, the sexual deviance of the siren who splits her tail is emphasized by the fact that she shares a capital with Luxuria, whose breasts are attacked by snakes. William J. Travis, "Of Sirens and Onocentaurs: A rouses the idea of an erect penis. As I will demonstrate, the crouching crossbowman's open mouth, fixed gaze, prominent hands, and pulling arms can be read as a reference to masturbation as one layer of meaning in this image's heightened sexual discourse. The twined string he pulls continues the line and echoes the curve of the women's ropy hair, tying the three figures together. ${ }^{5}$ Their common nakedness underscores the deviant nature of the crossbowman's actions, linking the rising use of this powerful weapon in turn-of-thetwelfth-century Christendom with a misuse of sexuality.

In this study, I bring the crouching crossbowman to scholarly attention in order to provide a first reading of this heretofore unexamined iconography, together with an explanation for the image's initial conception around 1100 and rapid disappearance a few decades later. These sculpted figures are not dressed as soldiers but shown naked, hunched down low, with knees splayed in a humiliating, revealing posture. They are nothing like the portrayals of men who use crossbows in the hunt or battle, which appeared in the same period and would become common throughout the Middle Ages as the

Romanesque Apocalypse at Montceaux-l'Étoile," Artibus et Historiae 23, no. 45 (2002): 29-62, esp. figs. 21-22. See also Jacqueline Leclercq-Marx, La sirène dans la pensée et dans l'art de l'Antiquité et du Moyen Âge: du mythe païen au symbole chrétien (Brussels: Académie Royale de Belgique, 1997).

5. I thank Peter Scott Brown for pointing out this telling detail to me.

$144 \therefore$ Gesta v54n2, Fall 2015 


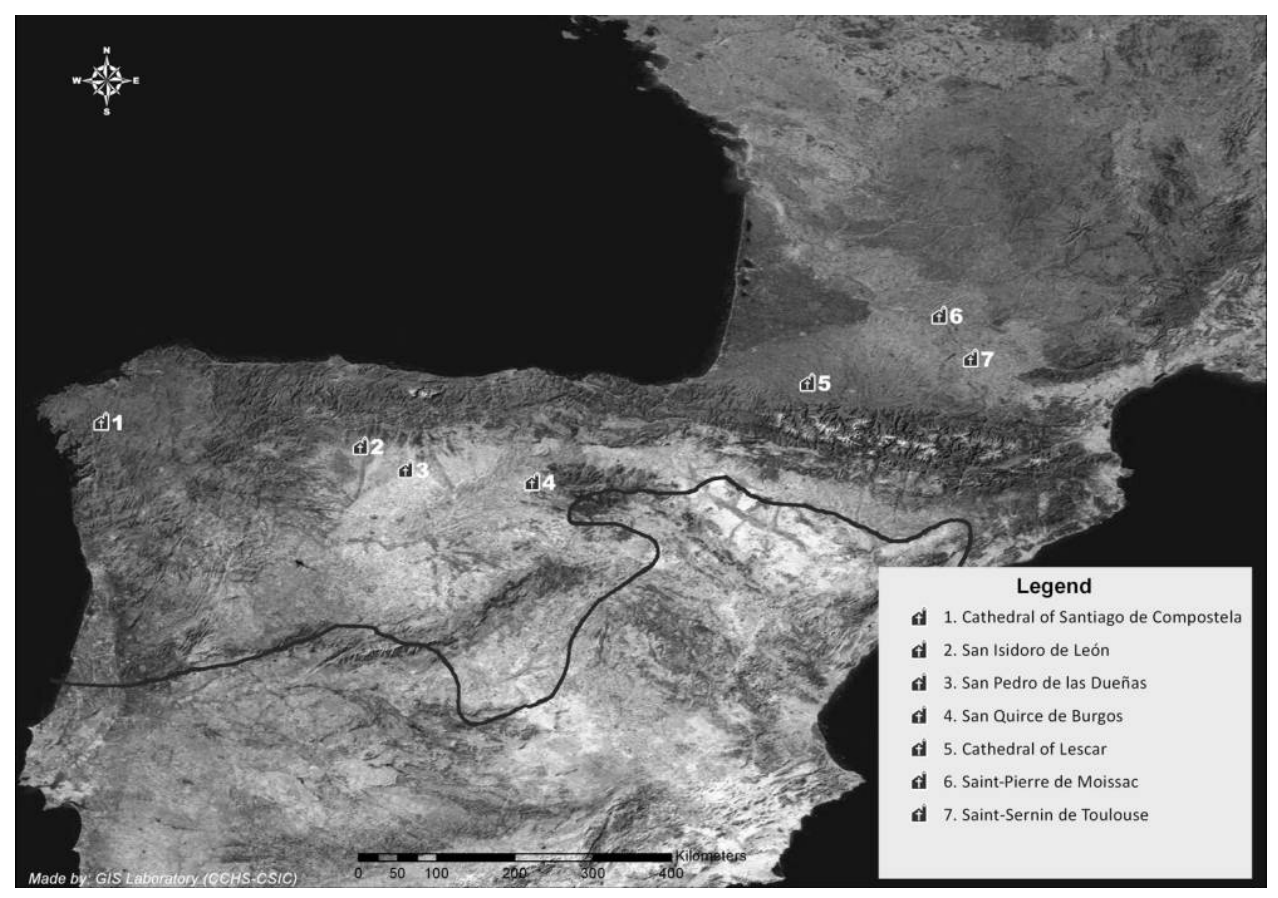

Figure 2. Locations of crouching crossbowmen, showing frontier between Christian and Islamic territories, ca. 1115 (map: author).

weapon was assimilated into the roster of standard armaments. ${ }^{6}$ Representations of mounted or standing men wielding crossbows, with positive or negative connotations depending on the larger setting, differ greatly from this uniformly negative group of Romanesque sculptures. ${ }^{7}$

6. With the identification of these figures I offer an art historical response to the military historian David S. Bachrach, "Crossbows for the King: The Crossbow during the Reigns of John and Henry III of England," Technology and Culture 45, no. 1 (2004): 102-19, esp. 111, who stated that "scholars working on medieval illustrations of crossbows have been unable to identify depictions of balistae ad duos pedes." For an important article concerning the difficulty of using artistic representations to study medieval weaponry, see Peter Dinzelbacher, "Quellenprobleme bei der Erforschung hochmittelalterlicher Bewaffnung," Mediaevistik 2 (1989): 43-79, esp. 46-61.

7. Sainte-Foy at Conques offers a contemporaneous example of a crossbow carried by a demon on the hell side of the tympanum; Kirk Ambrose, "Attunement to the Damned of the Conques Tympanum," Gesta 50, no. 1 (2011): 1-17, fig. 6. But the crossbow was not always portrayed as negative, even in Romanesque art. The same weapon, armed and ready to fire, is also wielded righteously by the first of the Four Horsemen of the Apocalypse on fol. 85v of the Beatus commentary on the Apocalypse from Burgo de Osma, dated 1086; John Williams, The Illustrated Beatus: A Corpus of the Illustrations of the Commentary on the Apocalypse, vol. 4, The Eleventh and Twelfth Centuries (London: Harvey Miller, 2002), 17-25, ills. 14.1-82. For later neutral or positive images, see Ada Bruhn de Hoffmeyer, Arms and Armour in Spain: A Short Survey (Madrid: Instituto de Estudios sobre Armas Antiguas, Consejo Superior de Investigaciones
In addition to San Isidoro in León, I have located crouching crossbowmen in just six other churches on both sides of the Pyrenees: the monasteries of Saint-Sernin de Toulouse, SaintPierre de Moissac, San Pedro de las Dueñas, and San Quirce de Burgos, and the cathedrals of Santiago de Compostela and Lescar (Fig. 2). ${ }^{8}$ While debate continues concerning the exact chronology of each of these sites, they can generally be dated within the first quarter of the twelfth century, except San Quirce, which is a decade or so later than the rest. The sculptures differ both in how each crossbowman is represented and in the larger composition within which he appears, but they all share the main distinguishing characteristic: a spreadlegged figure who crouches low to arm his weapon. They are all on or near the pilgrimage route to Compostela, which likely points more to the importance of these churches, built at the height of the Romanesque and ornamented with the most modern imagery, than to any specific connections with pilgrimage itself. As is well known, this artery facilitated the interchange of ideas and styles among Spanish and French

Científicas, 1982), 2:87-99, which includes examples of manuscript and mural paintings from thirteenth-century Christian Spain that show the crossbow in the hands of both Muslim and Christian soldiers. For later negative representations of bowmen, see Michael Camille, Image on the Edge: The Margins of Medieval Art (Cambridge, MA: Harvard University Press, 1992), 100-108.

8. I am grateful to Isabel del Bosque González of the Sistemas de Información Geográfica Unit (Centro de Ciencias Humanas y Sociales, CSIC) for working with me to create this map. 
polities. ${ }^{9}$ In the first quarter of the twelfth century the Christian lands to the south of this highway, recently wrested from the Muslims, were frontier territories. ${ }^{10}$ Although these areas were populated by Christians, no major Romanesque constructions were undertaken south of Palencia until the second half of the century, by which time the image of the naked, hunkered-down crossbowman had been abandoned. Because this iconography is found only during the early decades of the twelfth century and mainly at major ecclesiastical sites in what are now northern Spain and southern France, visual evidence affords us the opportunity to delve deeply into a concrete historical moment. My interpretation springs from visual analysis and weapon history, backed up by the scanty archaeological and written evidence (chronicles, charters, and laws), which, together with a "disciplined imagination,"11 allow us to understand the political and social context that gave rise to this evanescent iconography.

The appearance in Romanesque architecture of a naked crossbowman, not attired as a warrior or a hunter, who squats to span his weapon, provides an ideal case study for examining the impact of technology on society, the efficacy (or lack thereof) of censure by the Church, and the process behind the development of new iconographies. I argue that the short-lived, frontal view of the crouching crossbowman represents a shaming of violence and sexuality when carried out without ecclesiastical sanction. Each had its place: sexuality when directed toward procreation within a conjugal union received ecclesiastical blessing, while terrible weapons like crossbows could be approved for use as long as the enemy was not a fellow Christian, as underlined by the papal anathema discussed below. Concerning the licit use of violence by knights, Jonathan Alexander noted that there was "a moment ca. 1100 in which ideological pressures combined to put in place a positive image of the warrior," a figure that carried on throughout the Middle Ages. ${ }^{12}$ But the Church was not to be

9. For a historiographic summary of the vast literature on the Camino, see Paula Gerson, "Art and Pilgrimage: Mapping the Way," in A Companion to Medieval Art: Romanesque and Gothic in Northern Europe, ed. Conrad Rudolph (Malden, MA: Blackwell, 2006), 599-618.

10. For the concept of frontier, see Pascal Buresi, La frontière entre chrétienté et Islam dans la péninsule Ibérique: du Tage à la Sierra Morena (fin XIe-milieu XIIIe siècle) (Paris: Publibook, 2004); and Janice Mann, Romanesque Architecture and Its Sculptural Decoration in Christian Spain, 1000-1120: Exploring Frontiers and Defining Identities (Toronto: University of Toronto Press, 2009).

11. I borrow this felicitous phrase from Valerie L. Garver, Women and Aristocratic Culture in the Carolingian World (Ithaca, NY: Cornell University Press, 2009), 12.

12. Jonathan J. G. Alexander, "Iconography and Ideology: Uncovering Social Meanings in Western Medieval Christian Art," Studies in Iconography 15 (1993): 1-44, esp. 13. My reading of the as successful in promoting the iconography of the crouching crossbowman, a too-earthy foil to the good warrior. Conrad Rudolph, whose study of violence and spiritual struggle in the Cîteaux Moralia in Job is a model of how to understand unexpected iconographies in a manuscript setting, summed up best what I am attempting to do here: while he "readily affirm[ed] that all—or even the most important-meaning may not be found in texts, all meaning certainly must be appropriate to the context." ${ }^{13}$ No written source makes reference to these crossbowmen, nor do we have detailed information about the incorporation of crossbows in Christian armies at the turn of the twelfth century beyond what I lay out below. Nevertheless, visual analysis, together with an understanding of the specific historical context that saw the birth and death of this iconography, enables us to decipher the multiple meanings behind the ephemeral image. ${ }^{14}$ I do not pretend to offer a catalogue of the crossbow in Romanesque art but, rather, to determine the significance of its rare appearances in this specific guise. ${ }^{15}$ My aim is to understand both what this sculpted image means and why it had such a short life; in doing so, I intend to uncover its social history refracted through the prism of iconography.

A century later than the period on which this study focuses and a world away from major ecclesiastical sites, a corbel from the late Romanesque apse of the tiny church of Nuestra Señora del Castro shows a clear link between the crossbow and masturbation, carried out in the most basic of

crouching crossbowman responds directly to the author's statement (13) about the importance of charting "the appearance of new iconographies, which are indications of shifts in social or economic organization, and in ideological values."

13. Conrad Rudolph, Violence and Daily Life: Reading, Art, and Polemics in the Cîteaux "Moralia in Job" (Princeton: Princeton University Press, 1997), 12.

14. In this, my thinking aligns with the recent analysis of Romanesque carvings of centaurs in Kirk Ambrose, The Marvellous and the Monstrous in the Sculpture of Twelfth-Century Europe (Woodbridge: Boydell, 2013), 43-44, where he notes that "there is something lost in translation in these interpretations that rely heavily on exegetical treatises for their insights. For these do not explain precisely how theological speculations inform the specific articulation of sculptural forms. Such 'readings' ... ultimately do little to explain the physicality of these sculptural objects."

15. See, for example, the illustrations in Alessio Cenni, "The Diffusion of the Crossbow in Italian Warfare," Journal of the Society of Archer-Antiquaries 42 (1999): 46-54, esp. 46, which are drawn from twelfth-century Italian sources, including the Liber ad honorem Augusti and Peter of Eboli. They show crossbowmen carrying or firing their weapons, but never in the squatting position seen in these French and Spanish sculptures. I am grateful to Tessa Garton, Dorothy Glass, Antonio Ledesma, and Lisa Reilly for their help in confirming that representations of the crouching crossbowman appear to be unknown in Italian Romanesque sculpture.

$146 \therefore$ Gesta $\quad$ v54n2, Fall 2015 


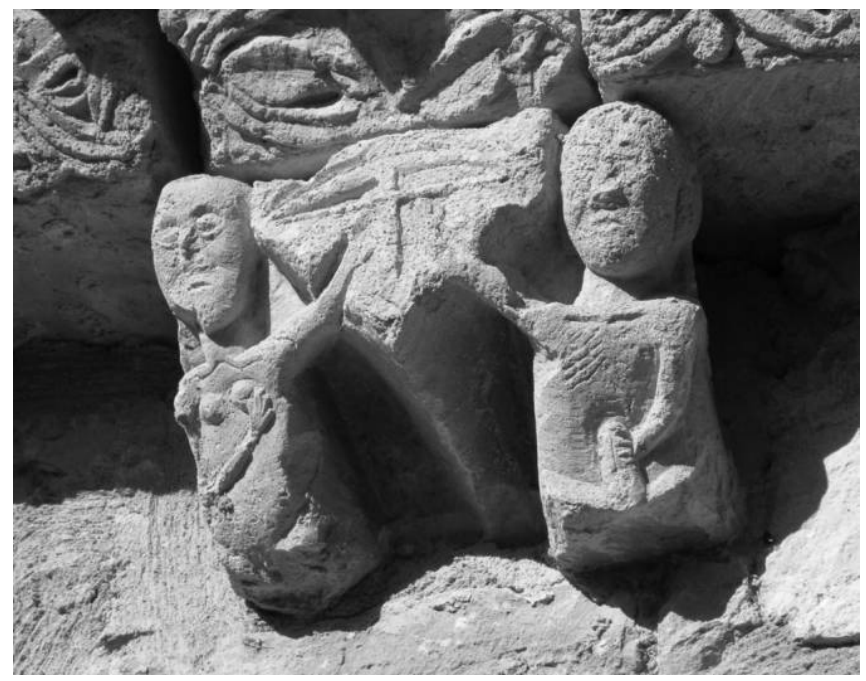

Figure 3. Crossbow corbel, Nuestra Señora del Castro, outside Momediano, first quarter of thirteenth century (photo: author). See the electronic edition of Gesta for a color version of this image.

carvings (Fig. 3). ${ }^{16}$ At this isolated location on the outskirts of the village of Momediano, tucked away in the hilly region north of Burgos, the man's gesture, as he grasps the shaft of his penis with one hand and reaches up with the other to touch the crossbow's string, is unequivocal. The weapon simultaneously joins and separates the couple, as the woman stretches out a hand toward its shaft. This visual play on words is likely deliberate, for verga in Spanish (originating as the Latin virga, meaning branch, rod) means both the stock of a crossbow and a cock, just as in English one cocks a weapon. ${ }^{17}$ Whether the woman's right hand is meant to be seen as caressing her own breast or raised to ward off the man is not clear. In either case, her partner's unambiguous action assured readability by rural viewers, making the Momediano corbel a rare holdover of a century-old idea that had by then

16. "Momediano, Nuestra Señora del Castro," in Enciclopedia del Románico en Castilla y León: Burgos (Aguilar de Campoo: Fundación Santa María la Real, Centro de Estudios del Románico, 2002), $3: 1825-28$. This image calls to mind the popular saying recorded by Christian Bougoux, Petite grammaire de l'obscène: églises du duché d'Aquitaine; XIe/XIIe s. (Bordeaux: Bellus Éditions, 1992), 151: "La femme est un arc, l'homme est la flèche, le diable tend la corde."

17. J. N. Adams, The Latin Sexual Vocabulary (Baltimore: Johns Hopkins University Press, 1990), 14-15. Madeline H. Caviness discussed this sort of wordplay in her analysis of a fourteenthcentury manuscript in which she also identified a marginal figure's crossbow as phallic. Caviness, "Patron or Matron? A Capetian Bride and a Vade Mecum for Her Marriage Bed," Speculum 68, no. 2 (1993): 333-62; repr. in Studying Medieval Women: Sex, Gender, Feminism, ed. Nancy F. Partner (Cambridge, MA: Medieval Academy of America, 1993), 31-60, 175-81, esp. 39-40. dropped out of currency at the major ecclesiastical centers, losing the obvious squatting position with which it began.

Masturbation was seen not only as a lowly vice that forestalled procreation and polluted the purity of the body but also one that deserved ridicule. ${ }^{18}$ Jeremy Adams notes that sexual metaphors in Greek and Latin "for the male organ derived from weaponry seem to have been risqué, and as such they were common in jokes and forms of comedy." He identifies the bow as one such metaphor because of the "capacity to tauten and relax," as well as "the 'horny' frame of the bow which suggests the male organ." ${ }^{19}$ On the San Isidoro capital (Fig. 1a), the deliberate ambivalence between the dangerously attractive female figures and the smaller, straining crossbowman warns the viewer not to give in to this grotesque type of carnality but to struggle against it. Masturbation seems to be suggested on this capital and the others addressed here by the frontal, crotch-displaying pose, which opens these crossbowmen to contempt. Whether or not the ancient precedent of masturbating satyrs was known to the twelfth-century patrons and sculptors who devised the crouching crossbowmen, such mockery had been the intended reaction to representations in Greek vase painting of squatting satyrs, whose "extraordinary sexual energy brings them closer to animals than to men ... and provokes laughter" (Fig. 4). ${ }^{20}$ François Lissarague explains that satyrs "spread their legs symmetri-

18. Thomas W. Laqueur, Solitary Sex: A Cultural History of Masturbation (New York: Zone Books, 2003), esp. 140-68. Laqueur traces in detail the sparse medieval references to masturbation, which appear in monastic sources and penitentials. See Pierre J. Payer, Sex and the Penitentials: The Development of a Sexual Code, 550-1150 (Toronto: University of Toronto Press, 1984), 46-47. For the particularities of the early Spanish church, especially the fourth-century Council of Elvira, see Gabriel Le Bras, "Notes pour servir à l'histoire des collections canoniques, V: Iudicia Theodori; VI: Pénitentiels espagnols," Revue historique de droit français et étranger, 4th ser., 10 (1931): 95-131; Severino González Rivas, La penitencia en la primitiva Iglesia española: estudio histórico, dogmático y canónico de la penitencia en la Iglesia española, desde sus orígenes hasta los primeros tiempos de la invasión musulmana (Salamanca: Instituto San Raimundo de Peñafort, 1949); and Manuel C. Díaz y Díaz, "Para un estudio de los penitenciales hispanos," in Études de civilisation médiévale, IXe-XIIe siècles: mélanges offerts à Edmond-René Labande. . . . (Poitiers: C.É.S.C.M., 1974), 217-22.

19. Adams, Latin Sexual Vocabulary, 21-22.

20. François Lissarague, "The Sexual Life of Satyrs," in Before Sexuality: The Construction of Erotic Experience in the Ancient Greek World, ed. David M. Halperin, John J. Winkler, and Froma I. Zeitlin (Princeton: Princeton University Press, 1990), 53-81, esp. 56-57. In Attic painting, the satyr's "crouching posture is not that of the honest Athenian. It is a posture with a specific meaning, and it is usually reserved by the painters either for defecation or for inferiors, like slaves." 


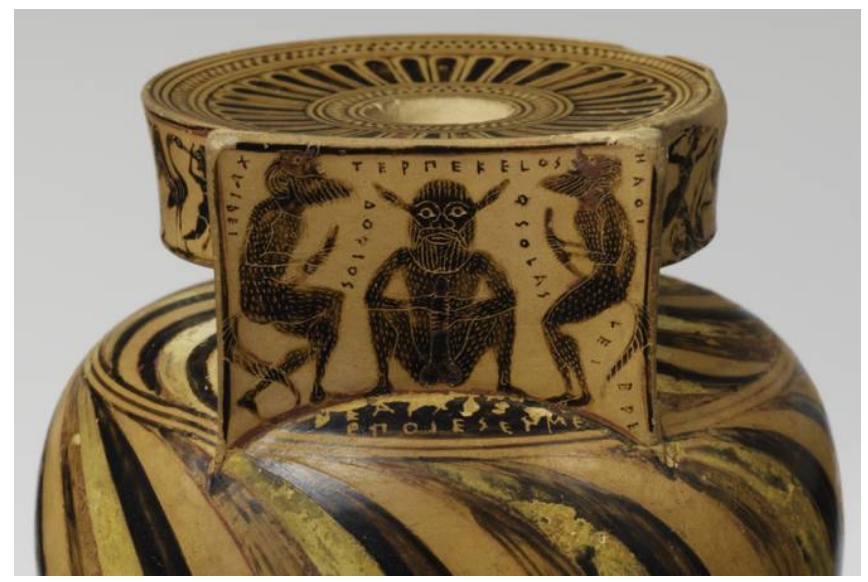

Figure 4. Squatting satyr, detail of Attic black-figure aryballos, signed Nearchos, ca. 570 BCE, Metropolitan Museum of Art, Purchase, The Cesnola Collection, by exchange, 1926, 26.49 (photo: Metropolitan Museum of Art).

cally, showing their genitals, thus adding indecency to the humility of their posture." ${ }^{21}$

Pointing out that crouching is often associated with masturbation, Thomas Laqueur clarifies that

[s]atyrs did it because that is the sort of creatures they were-beasts with big genitals, limitless sexual appetites, and little education. Of course they masturbated; what was one to expect? ... Depictions on pottery of free men-as opposed to satyrs or slaves-masturbating are rare and are always of bumpkins or rustics, never of citizens. ... In short, male masturbation was a joke - the butt of comedy and derision. ${ }^{22}$

Laqueur notes that churchmen began to pay increased attention to masturbation around 1100 , just when the new iconography of the crouching crossbowman was created. ${ }^{23}$ These sculptures appear during the great ecclesiastical shift now known as the Gregorian Reform, when purity in the clergy, especially the issue of priestly marriage, came to the fore. ${ }^{24}$ Other aspects of the desired purity of the priesthood took hold more strongly in the thirteenth century, when writers focused in detail on the matter of masturbation. Dyan Elliott

21. Ibid., 56-57.

22. Laqueur, Solitary Sex, 103.

23. Ibid., 135.

24. Dyan Elliott, Fallen Bodies: Pollution, Sexuality, and Demonology in the Middle Ages (Philadelphia: University of Pennsylvania Press, 1999); and Michelle Armstrong-Partida, "Priestly Marriage: The Tradition of Clerical Concubinage in the Spanish Church," Viator 40, no. 2 (2009): 221-53. cites the story by Thomas of Cantimpré (d. ca. 1272) in which "a cleric reached down to touch himself, only to discover that his penis had turned into a serpent." ${ }^{25}$ Of even greater concern were nocturnal emissions, but, as Elliott notes, these "received only the most routine treatment (mainly in penitential literature) from the seventh until the twelfth century, and thereafter commanded increased attention until the end of the Middle Ages." ${ }^{26}$ Perhaps one element of the ephemeral nature of the crouching crossbowman iconography has to do with its creation before questions of individual sexual sin were foregrounded by Church writers. There is an ambivalence to these figures that makes them more objects of humiliating derision than of canonical condemnations seen subsequently in written sources. In their Romanesque iteration, the crossbowmen's masturbatory gesture seems intended to elicit a mocking contempt that is not present in the later, more detailed medieval texts documented by Elliott.

As for the weapon itself, the crossbow was dangerous, effective, and beginning to gain in prominence at the turn of the twelfth century, having long been known in China, the Islamic world, and the West yet without being widespread among European soldiery since the Roman era. ${ }^{27}$ As David Bachrach noted, "By the second half of the twelfth century, and throughout the thirteenth, the crossbow was the dominant handheld missile weapon in most of western Europe," used especially in siege warfare. ${ }^{28}$ In addition, there was a more sinister side to the device: with little training, a crossbow could be wielded by anyone, allowing lowly peasants to defeat mounted knights or a woman to rebel against her liege, as in a story by Orderic Vitalis recounted below. This

25. Elliott, Fallen Bodies, 45-47, 191n59, citing Thomas of Cantimpré, Bonum universale de apibus (Douai: Belleri, 1627), 2.30.6, p. 322.

26. Elliott, Fallen Bodies, 15; and Payer, Sex and the Penitentials, 49-52. On the contribution of monstrous Romanesque imagery to neutralizing nocturnal pollution, see Thomas E. A. Dale, "Monsters, Corporeal Deformities, and Phantasms in the Cloister of St-Michelde-Cuxa," Art Bulletin 83, no. 3 (2001): 402-36, esp. 427-30.

27. I am grateful to Kelly DeVries for helping to orient my reading in medieval weapon history at an early stage of my research. For general studies of the crossbow, see Ralph Payne-Gallwey, The Crossbow: Its Military and Sporting History, Construction and Use (London: Longmans, Green, 1903; facsimile ed., New York: Skyhorse Publishing, 2007); Josef Alm, European Crossbows: A Survey, trans. H. Bartlett Wells (Leeds: Royal Armouries Museum, 1998), 107255; Egon Harmuth, Die Armbrust (Graz: Akademische Druck- u. Verlagsanstalt, 1975); Kelly DeVries, A Cumulative Bibliography of Medieval Military History and Technology (Leiden: Brill, 2002; updated 2005, 2008); and Dirk Breiding, A Deadly Art: European Crossbows, 1250-1850 (New York: Metropolitan Museum of Art, 2013).

28. Bachrach, "Crossbows for the King," 102.

$148:$ Gesta v54n2, Fall 2015 
constituted a reversal in the correct order of medieval society, upsetting the established hierarchy. For unlike a regular bow, which required a strong arm to pull back the string and steadily hold the arrow in place while aiming, a crossbow, once armed, took little strength to aim and fire. I see the crossbow's potential to destabilize social structures and political networks over which the Church exercised authority as a key reason that the weapon was verbally denounced and visually discredited in the first decades of the twelfth century.

As the Romanesque representations bear witness, the most characteristic element of the early crossbow was the full-body physicality of the position required to arm it. That is, when the crossbow was on its way to becoming a conventional weapon of war, the pre- 1100 version needed great strength to span the large duos pedes type: two feet had to press down on the bow, while two hands pulled the string up along the stock in order to lock it into place with the nut. Improvements were soon made. First, a stirrup was added to the stock so that a soldier or hunter could step with just one foot. A hook hanging from the belt also aided with the spanning, whether the crossbowman was standing or on horseback. ${ }^{29}$ Finally, a winch or crank made the spanning easier to accomplish and multiplied the weapon's firing power. ${ }^{30}$ The shift from two-foot to stirrup crossbow was not just a chronological development but a parallel sophistication: the two-foot variety continued in use as the strongest crossbow, while the stirrup appeared on a lighter version more appropriate for the hunt or cavalry than for siege warfare. These technological enhancements radically changed the bodily interaction between wielder and weapon. The stirrup and then mechanization shifted the posture for spanning from an open-legged squat to one less revealing, which in turn elevated the weapon to a higher status. It was the former posture-rude, sexually revealing, apelike-as an essential element of the early crossbow that is the common factor in our Romanesque sculptures.

For an extreme articulation of the unseemly position needed to span a two-foot crossbow, we can turn to Anna Comnena (d. ca. 1153), daughter of the Byzantine emperor Alexius Comnenus (r. 1081-1118) and chronicler of his reign. In the Alexiad, completed about 1148, she describes in exaggerated terms both the bodily involvement in arming the weapon and its appalling efficacy at a time when the crossbow was not in common use by the Byzantines. The uncouth Western Christians were said to have brought it along with them on what is now known as the First Crusade. Based on her report of a sea battle near Epidamnus in December

29. Egon Harmuth, "Concerning the One-Foot Crossbow of the High Gothic," Journal of the Society of Archer-Antiquaries 28 (1985): 9-12.

30. Bachrach, "Crossbows for the King," 109.
1096, Anna's disparagement of the crusaders as barbarians is frequently cited in military literature; here she makes the crossbow an essential element of the Westerners' foreign and ignoble character.

Marianus [a Byzantine general], speaking in their language, advised the Latins to have no fear, and not to fight against fellow-Christians. But one of the Latins hit his helmet with his crossbow. The crossbow is a weapon of the barbarians, absolutely unknown to the Greeks. In order to stretch it one does not pull the string with the right hand while pushing the bow with the left away from the body; this instrument of war, which fires weapons to an enormous distance, has to be stretched by lying almost on one's back; each foot is pressed forcibly against the half-circles of the bow and the two hands tug at the string, pulling it with all one's strength towards the body. [The bolts] are very short, but extremely thick with a heavy iron tip. In the firing the string exerts tremendous violence and force, so that the missiles wherever they strike do not rebound; in fact, they transfix a shield, cut through a heavy iron breastplate and resume their flight on the far side, so irresistible and violent is the discharge. An arrow of this type has been known to make its way right through a bronze statue, and when fired at the wall of a very great town its point either protruded from the inner side or buried itself in the wall and disappeared altogether. Such is the crossbow, a truly diabolical machine. ${ }^{31}$

With this vivid description, there can be little doubt that, before the addition of a stirrup, the position required to span the crossbow was a most recognizable characteristic of this weapon and its contemptible "barbarian" wielder. Its distinctive gesture was seized on by the unknown designers of the new Romanesque iconography to embody the idea of brute sexuality in the permanence of sculpture.

Reduced to its simplest form at Santiago de Compostela, a crouching crossbowman once located on the cathedral's lost north portal now appears on the south facade of the great pilgrimage destination (Fig. 5). ${ }^{32}$ This small nude figure, only the

31. Anna Comnena, The Alexiad of Anna Comnena, trans. E. R. A. Sewter (London: Penguin Books, 1969), 316-17. See also P. Stephenson, "Anna Comnena's Alexiad as a Source for the Second Crusade?," Lournal of Medieval Historv 29, no. 1 (2003): 41-54.

32. Manuel Castiñeiras, "La meta del Camino: la catedral de Santiago de Compostela en tiempos de Diego Gelmírez," in Los caminos de Santiago: arte, historia, literatura, ed. María del Carmen Lacarra Ducay (Zaragoza: Institución Fernando el Católico, 2005), 213-52, at 232, sees the crossbowman as one of the "personificaciones profanas del pecado," identifying as other members of this group a 


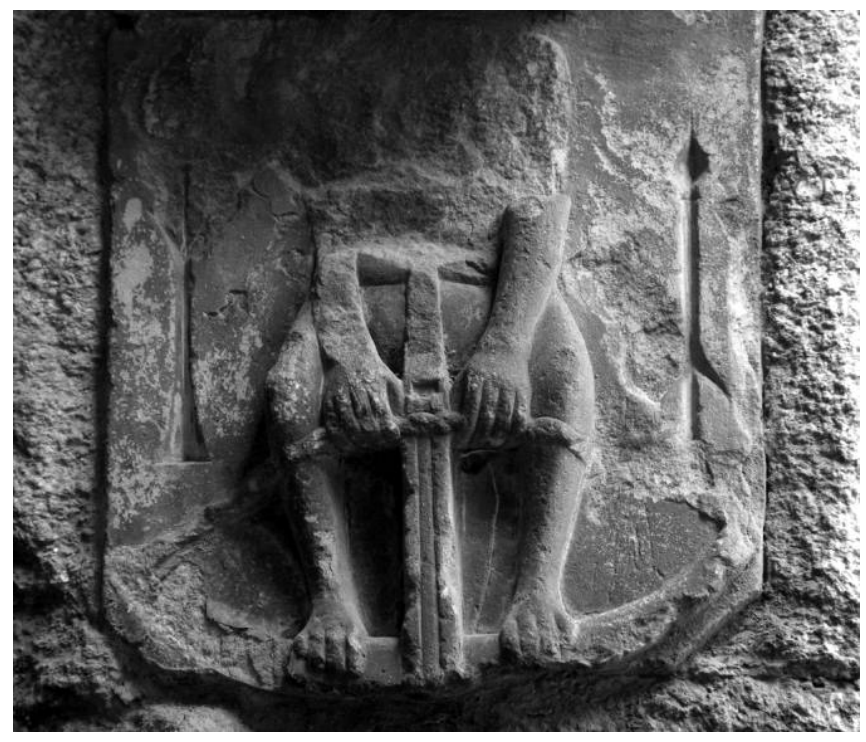

Figure 5. Crouching crossbowman, originally on north portal, now on south facade, cathedral of Santiago de Compostela, first quarter of twelfth century (photo: author). See the electronic edition of Gesta for a color version of this image.

lower half of which survives intact, has been sculpted in relief, flanked by a pair of bolts, or quarrels, incised into the stone. While the naked crouch tells the story, the loss of his head makes it impossible to know if this crossbowman, like other examples in this study, was either simian or monstrous; the presence of only four toes on each pawlike foot is an indication that he is somehow less than fully human. At Santiago, the crossbowman is pared down to the most elemental expression of this iconography: we see the creature squat as he pulls the string along the grooved stock; it is just about to be locked into place with the finely detailed nut before the weapon is raised and fired. The thrust of the action is down at the viewer, who would have looked up at this relief plaque, up at his squatting haunches for a sight that made much clearer than a head-on photograph does that the stock of the weapon in each of these sculptures stands in for an erect phallus. As with the other figures in this group, we are not being shown a warrior who points a loaded weapon at an enemy. Rather, the lowly creature is apprehended in the moment before his

figure mounted on a rooster and a centaur who has shot an arrow into a siren. For the larger context of the transept portals, see John Williams, "Framing Santiago," in Romanesque Art and Thought in the Twelfth Century: Essays in Honor of Walter Cahn, ed. Colum Hourihane (Princeton: Index of Christian Art, Dept. of Art \& Archaeology, Princeton University in association with Penn State University Press, 2008), 219-38; and Manuel Castiñeiras, ed., Compostela y Europa: la historia de Diego Gelmírez (Milan: Skira, 2010), esp. 49-84.

$150 \therefore$ Gesta $\quad$ v54n2, Fall 2015 weapon is fully armed; in symbolic terms, it seems to be the point of decision. Might we see in this figure a representation of the intent to sin? While I am hesitant to state this interpretation definitively, it cannot be accidental that the spanning of the crossbow is incomplete, as seen with greatest clarity in the example at Compostela.

A more complex version of this iconography was devised for the pair of crouching crossbowmen at Saint-Sernin in Toulouse, where sexuality is coupled with a deriding of violence on an interior capital located on the south wall near the west end (Fig. 6a). ${ }^{33}$ Here, cropped curls and lack of breasts give a masculine cast to the smooth-skinned, androgynous figure at the center of the composition. In each hand he grasps a bolt, which meet threateningly at his groin to signal the locus of sin. The corners of this capital feature two nude creatures, frozen in the moment of spanning their crossbows. They are not wholly human-the witless, open-mouthed expression of the figure at the right and the gaping nostrils of both are most commonly seen on apes in Romanesque sculpture, while the flamelike hair of the figure on the left recalls that of demons (Fig. 6b). ${ }^{34}$ As Jean Wirth noted in his study of Romanesque imagery, when a naked figure has bestial or exaggerated features the meaning of its nakedness is negative, degraded, "infrahumaine." 35 This capital has frequently been used to illustrate texts on the history of medieval arms because of the clarity and precision with which the weapons are represented. It must be noted, however, that these oafish crossbowmen are being mocked: they have taken a position that will make it impossible to complete the spanning of their bows. Rather than drawing the string up properly before them, they pull it behind their bent legs (compare Fig. 6b with Fig. 1a). When they try to straighten up, they will discover that the arming cannot be completed: these apelike men have been trapped by the folly of their own actions. In fact, if we set these two

33. Quitterie Cazes and Daniel Cazes, Saint-Sernin de Toulouse: de Saturnin au chef-d'oeuvre de l'art roman (Graulhet: Odyssée, 2008), 181-83. Without commenting on the significance of the figures' nakedness, the authors correctly note that "[c]et unique chapiteau historié dans la nef, le premier visible en entrant dans le collatéral sud par qui arrivait du portail occidental, se comprend comme une actualisation du refus de la violence par l'Église, présent sous d'autre formes dans le chevet."

34. For demons with exaggeratedly flaming hair and a discussion of the meanings of hair in Romanesque sculpture, see Kirk Ambrose, The Nave Sculpture of Vézelay: The Art of Monastic Viewing (Toronto: University of Toronto Press, 2006), 73.

35. Wirth, L'image à l'époque romane, 277: "la nudité reste souvent liée à la sexualité, mais contribue à la dégrader, comme dans les représentations de la luxurieuse tétée par des serpents. ... Comme l'homme descend par sa concupiscence au-dessous de la condition humaine, on pouvait représenter le bas du corps, siège des instincts qui le dégradent, sous une forme infrahumaine, animale ou végétale." 

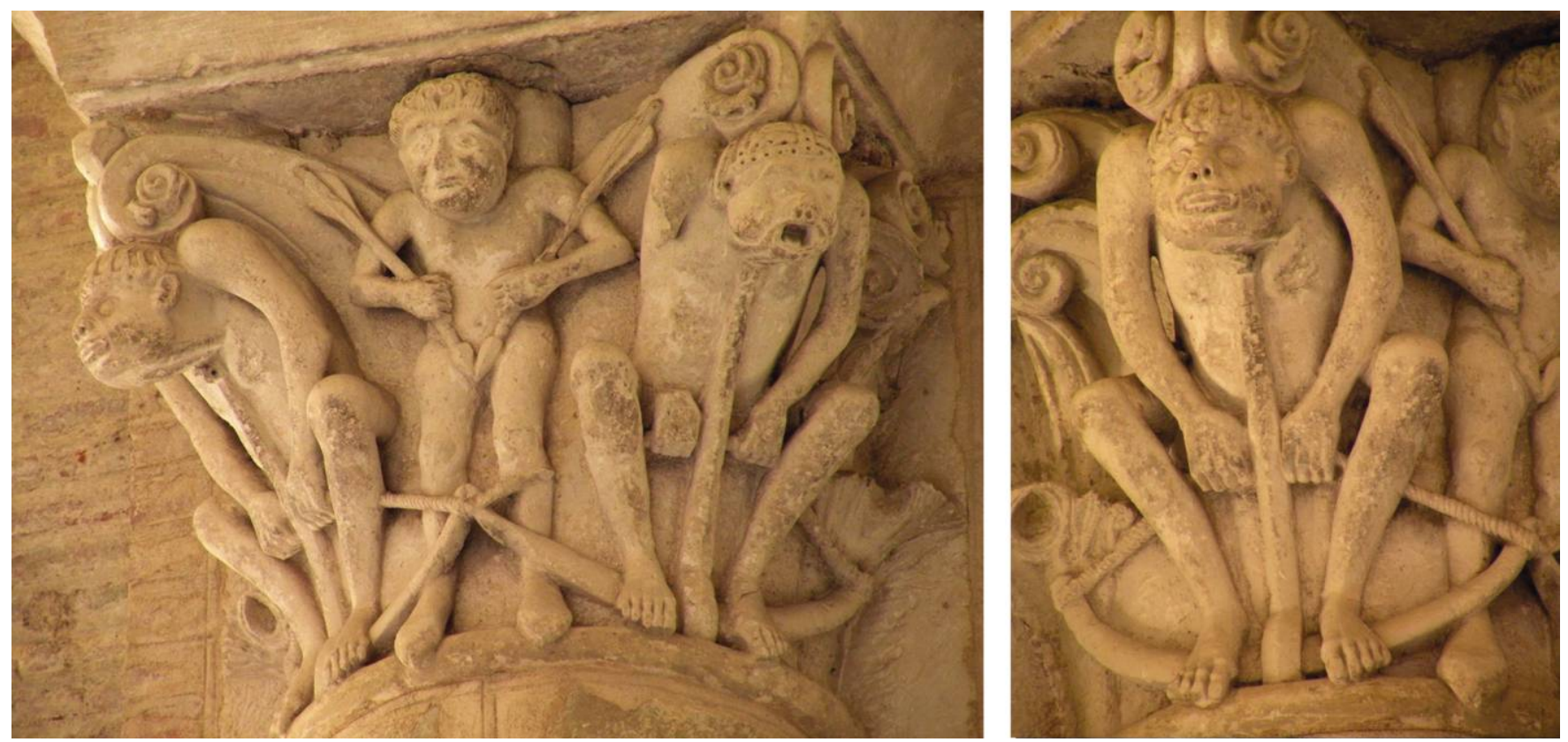

Figure 6a-b. Capital with bolt carrier and crouching figures with crossbows, and detail of left figure, west end of south wall, Saint-Sernin, Toulouse, first quarter of twelfth century (photos: author).

crossbowmen in motion, they will strain upward only to be forced down, again and again. This telling detail allows the viewer to feel a sense of superiority over the savage figures who have been caught in their misguided act.

On the Toulousan capital, the crouching and corrupted creatures who cannot stand recall an aspect of the interpretation made by Otto Karl Werckmeister in his classic analysis of Eve's pose on the lost north portal of Autun Cathedral. ${ }^{36}$ In her case, the position signaled both fall and penitence, but Werckmeister's citation of "man's loss of his erect stance in Gregory the Great's Moralia in Job" is also applicable to these sculpted crossbowmen:

For this purpose was man created that he, with a mind standing upright, should erect himself to the full height of contemplation, and no corruption should deflect him from the love for his creator. But since he moved the foot of his will away from the innate firmness of his standing [mind] towards guilt, he instantly fell from the love for his creator unto himself ... he could not stand up by himself, because, collapsing below himself, through corruption, under the impulse of his slippery changeability, he also came into conflict with himself. ... For

36. O. K. Werckmeister, "The Lintel Fragment Representing Eve from Saint-Lazare, Autun," Lournal of the Warburg and Courtauld Institutes 35 (1972): 1-30. because the mind was unwilling to stand firm while it could, now it cannot stand even when it wants to. ${ }^{37}$

Although the sculpted crossbowmen may be brought low by their own corrupt actions, there is a surprising sensuousness to the accompanying figures on this capital and the one at San Isidoro (Fig. 1a). Both the Leonese women and this androgyne are exposed and attractive, rendered erotically to please the eye. As Ruth Mazo Karras aptly observed, "Women's sexuality threatened medieval men in many ways: they might be temptresses and lure men into fornication or worse sins, they might behave in masculine ways with each other and so usurp male gender privilege, or they might use sexuality in other ways to control men." 38 These figures are designed to elicit a carnal, even visceral response from the viewers, who are enjoined, by means of the visual juxtaposition of the sensual with the degrading, to reject this response. The Toulousan capital (Fig. 6a) goes a step further than the Leonese example: the sensual central figure's genital region is made the focus of the viewer's attention by the diagonals of the bolts, which draw the eye directly to the seat of culpability. At the same

37. Ibid., 25, citing Moralia in Job 8.9.19, Gregory the Great, Opera Omnia, in Patrologiae Cursus Completus: Series Latina, ed. J.-P. Migne, 221 vols. (Paris: Garnier, 1844-64) (hereafter Migne, PL), 75 (1862): col. 813A-B.

38. Ruth Mazo Karras, Sexuality in Medieval Europe: Doing unto Others (New York: Routledge, 2005), 116. 
time, the emasculating threat inherent in these bolts evokes a sort of empathetic cringe, echoing the worried look on the figure's face. This capital seems intent on provoking paradoxical emotions, at once arousal and rejection. ${ }^{39}$ To the modern eye, the exquisitely carved figures accompanying the crossbowmen at Saint-Sernin and San Isidoro are more attractive than any repulsion that might be caused by the overtly revealing squat of the nearby creatures bearing weapons. Perhaps the medieval viewer had a similar response, which would go some way toward explaining why other sculptures in this group eliminate any sensual figures and focus directly on the crouching crossbowmen, emphasizing their bestiality.

Indeed, it is this very animal nature, embodied as it was by the Romanesque ape, that underlies the crossbowman iconography. ${ }^{40}$ We saw it just hinted at in the Toulousan capital, but the ape appears with perfect clarity in the example at the cathedral of Lescar discussed below. I contend that the familiar image of the squatting ape, with its connotations of brute lust and nasty habits, was borrowed for the creation of this new iconography. In contrast to the limited number of sites that exhibit sculptures of naked crossbowmen, the ape's crouching figure is ubiquitous in twelfth-century sculpture. Considered a relative of demons and monsters, the ape through its very name indicates that he copies what man does, as Hildegard of Bingen wrote in her Physica (ca. 1151-58): Since the ape is "rather similar to man, he always observes him in order to imitate his actions. He also shares the habits of

39. Jeffrey Jerome Cohen, "Monster Culture," in Monster Theory: Reading Culture, ed. Jeffrey Jerome Cohen (Minneapolis: University of Minnesota Press, 1996), 3-25, esp. 17, notes that "this simultaneous repulsion and attraction at the core of the monster's composition accounts greatly for its continued cultural popularity." See also Dale, "Monsters, Corporeal Deformities and Phantasms," 407.

40. The classic study is H. W. Janson, Apes and Ape Lore in the Middle Ages and the Renaissance (London: Warburg Institute, University of London, 1952). See also Serafín Moralejo, "El claustro de Silos y el arte de los caminos de peregrinación," in El románico en Silos: IX centenario de la consagración de la iglesia y claustro, 10981998 (Burgos: Abadía de Silos, 1990), 203-23; and Dale, "Monsters, Corporeal Deformities and Phantasms," 414-18. For many and varied examples of obscene squatting figures in French Romanesque churches, see Bougoux, Petite grammaire de l'obscène, 96-98. In a late thirteenth-century book of hours held by the Walters Art Museum, an ape can be seen aiming an armed crossbow at a horn-blowing man riding atop an elephant's back (MS W.102, fol. 28r; http://art .thewalters.org/detail/90296//); I have found no earlier explicit association between ape and crossbow. See Lilian M. Randall, "An Elephant in the Litany: Further Thoughts on an English Book of Hours in the Walters Art Gallery (W.102)," in Beasts and Birds of the Middle Ages: The Bestiary and Its Legacy, ed. Willene B. Clark and Meradith T. McMunn (Philadelphia: University of Pennsylvania Press, 1989), 97-107.

$152:$ Gesta $\quad$ v54n2, Fall 2015

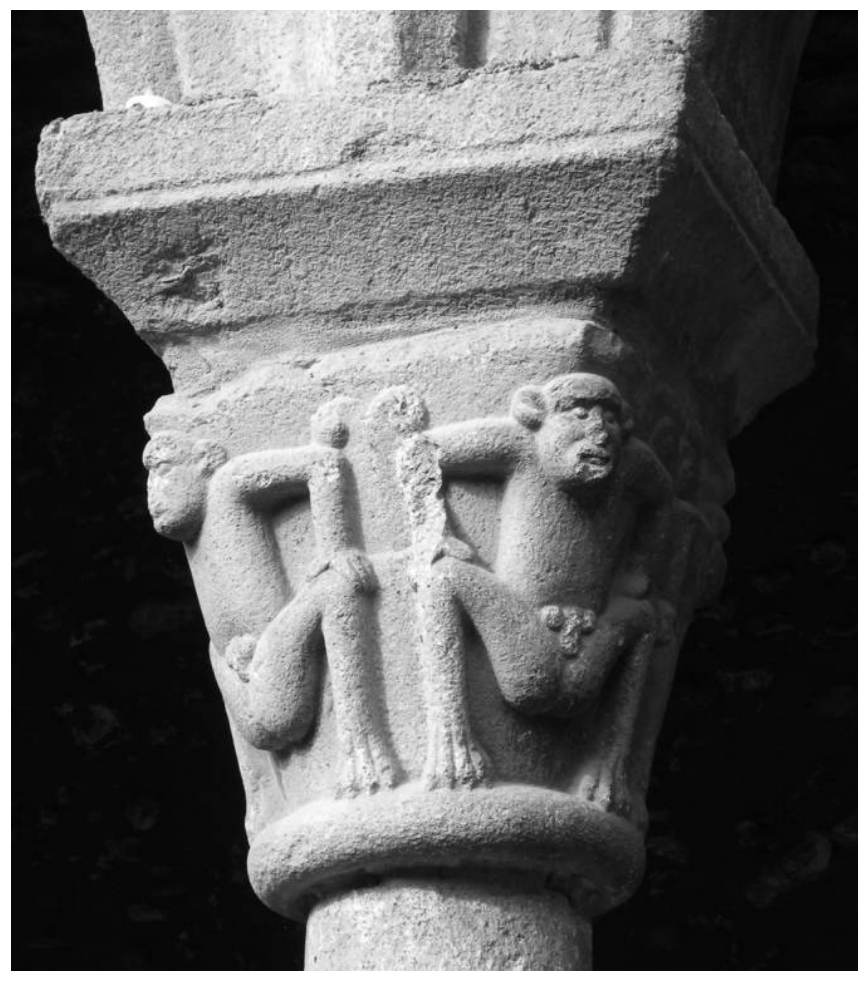

Figure 7. Capital with crouching apes, cloister of Santa María, Seu d'Urgell, first quarter of twelfth century (photo: author). See the electronic edition of Gesta for a color version of this image.

beasts, but both these aspects of his nature are deficient, so that his behavior is neither completely human nor completely animal." ${ }^{41}$ The cloister of Seu d'Urgell in the Pyrenees provides multiple squatting examples of these "deficient" beasts (Fig. 7). One capital both recalls and amplifies the words of the Physiologus, in comparing the appearance of the ape to that of a devil: "He had a beginning, but he has no end (that is, no tail); at the outset he was one of the archangels, but his end is not in view. Now the ape, not having a tail, is without species, and his rear, without a tail, is vile; like the devil, he does not have a good end." 42 While many representations of apes display their buttocks, the Seu d'Urgell sculpture adds the explicit exhibition of the genitals as well, repeated at the four corners of the capital..$^{43}$ Arms akimbo and knees splayed,

41. Janson, Apes and Ape Lore, 75-77, citing Hildegard of Bingen, in Migne, PL 197 (1855): col. 1329.

42. Janson, Apes and Ape Lore, 16-17, citing Francis J. Carmody, ed., Physiologus Latinus, Versio Y (Berkeley: University of California Press, 1941), 121.

43. Jordi Vigué, ed., Catalunya romànica, vol. 6, Alt Urgell, Andorra (Barcelona: Fundació Enciclopèdia Catalana, 1992), 31362, esp. 338. 

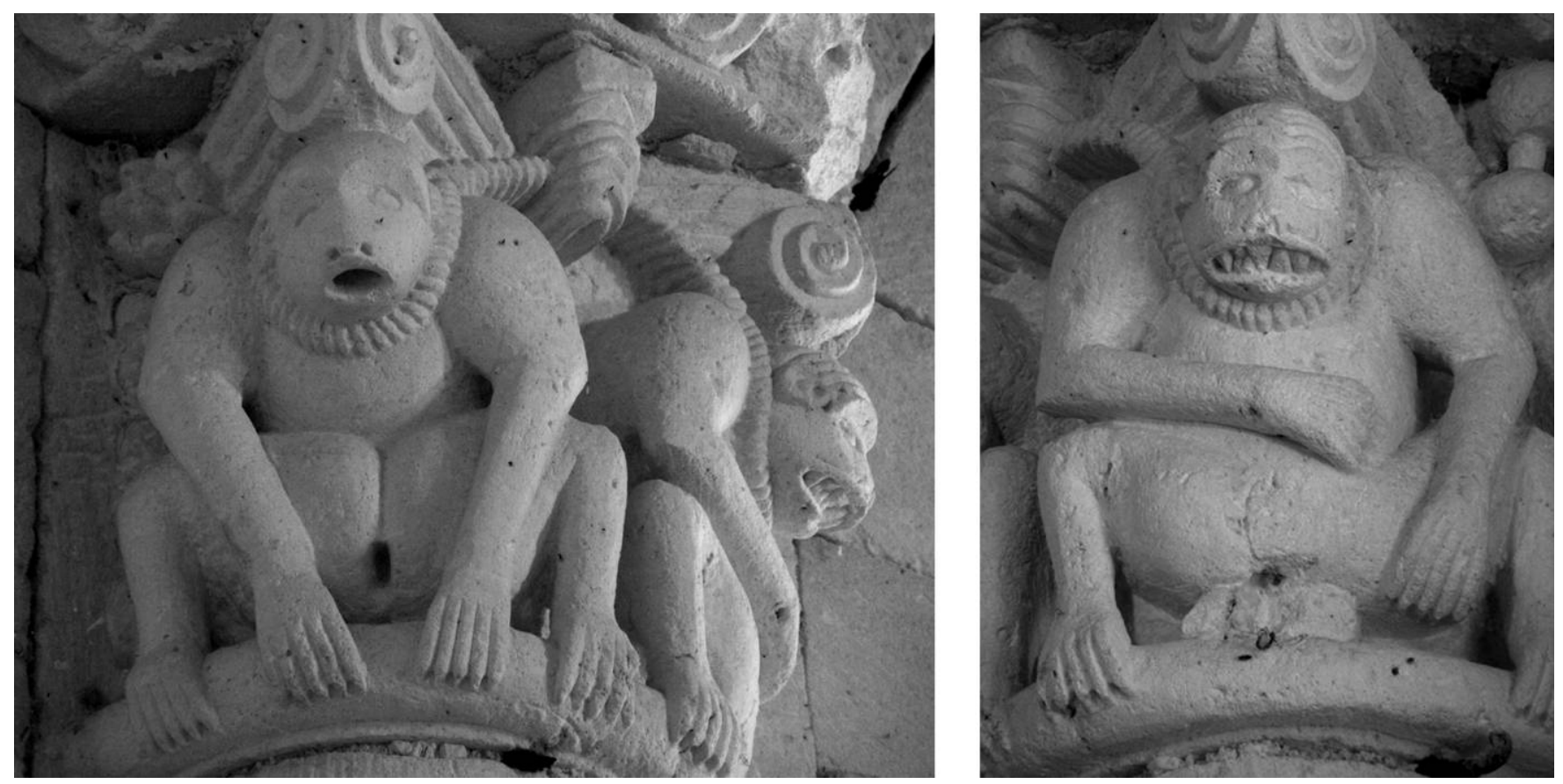

Figure 8a-b. Capital with female (left) and male (right) apes, apse, San Quirce, ca. late 1090s (photos: author). See the electronic edition of Gesta for color versions of these images.

these indecent apes, turpissimas bestias, copy men's actions by shamefully exposing what should remain covered up. ${ }^{44}$

Although crouching apes with widespread legs tend to be gender-neutral or male, ${ }^{45}$ an unusually explicit image of both sexes bound together by their lust can be seen on an apse capital at San Quirce in the province of Burgos, probably from the late 1090 s. $^{46}$ On the left, the female ape's vulva is indicated by a deep cleft, while her penetrability is doubled by the open-mouthed expression common to Romanesque

44. Janson, Apes and Ape Lore, 19-20. Dale, "Monsters, Corporeal Deformities and Phantasms," 414, discusses two capitals at Cuxa with pairs of squatting naked men and apes.

45. See, however, the obviously female ape on a corbel at Santiago Cathedral: Manuel A. Castiñeiras González, "A poética das marxes no románico galego: bestiario, fábulas e mundo ó revés," Semata 14 (2002): 293-334, fig. 14.

46. This fascinating building has unjustifiably fallen through the historiographic cracks. It is currently the topic of a dissertation at the Courtauld Institute of Art by Amanda Dotseth, "San Quirce de Burgos: Piety and Patrimony in the Long Life of a Romanesque Church." Previous brief studies include Justo Pérez de Urbel and Walter Muir Whitehill, "La iglesia románica de San Quirce," Boletín de la Real Academia de la Historia 98 (1931): 795-812; and José Pérez Carmona, Arquitectura y escultura románicas de la provincia de Burgos (Madrid: Ediciones Aldecoa, 1974), esp. 135-42. For an erudite analysis of the inscriptions on the west facade, see Daniel Rico Camps, Las voces del Románico: arte y epigrafía en San Quirce de Burgos (Murcia: Nausícaä, 2008). apes (Fig. 8a). ${ }^{47}$ By contrast, the unusually sharp-toothed grimace of her partner implies his violent character (Fig. 8b). Only the male creature's masturbatory gesture remains, as his penis has fallen victim to the bowdlerization of a later time. This is also the case with the erasure of both genitalia and clutching paws from two simian creatures on a capital at Saint-Gaudens, not far from the cathedral of Lescar (Fig. 9). ${ }^{48}$ Here the cord around the masturbating animals' necks is repeated, but rather than binding them together the rope passes through the hands of three intervening male figures, who seem to be restraining the beasts. Two other early examples of masturbating apes can be found in a window capital in the south apse of Jaca Cathedral and in a cloister capital at San Isidoro in León, both from the 1090s, that is, at a moment just before the creation of the crossbowman

47. For a discussion of explicit representations of female nudity in medieval art, see Madeline H. Caviness, "Retomando la iconografía vaginal/Revisiting Vaginal Iconography," Quintana: Revista de Estudos do Departamento de Historia da Arte 6 (2007): 13-37.

48. Marcel Durliat, La sculpture romane de la route de SaintJacques: de Conques à Compostelle (Mont-de-Marsan: Comité d'Études sur l'Histoire et l'Art de la Gascogne, 1990), 298-307. In idem, "Les chapiteaux romans de léglise de Saint-Gaudens," Revue de Comminges 95 (1982): 31-70, at 38, the author characterized this capital as expressing "un dérèglement sexuel dénoncé par la morale chrétienne." 


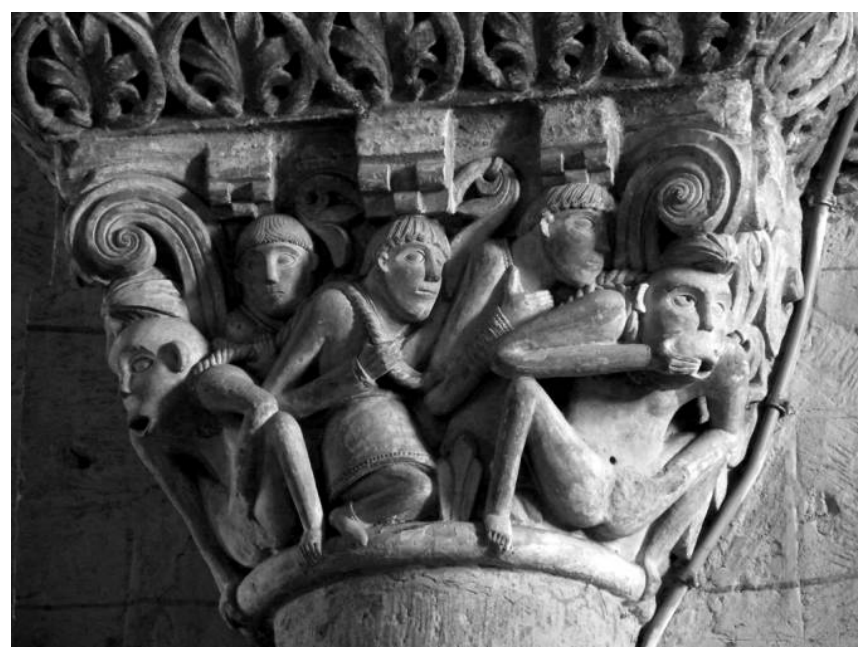

Figure 9. Capital with censored apes and men, nave, Saint-Gaudens, first quarter of twelfth century (photo: author). See the electronic edition of Gesta for a color version of this image.

iconography. ${ }^{49}$ The image of the masturbating ape served as inspiration for the crouching crossbowman, offering a model that could be easily adapted and would have been immediately comprehended by a wide audience. While explicitly represented masturbating human figures are well known from their appearances on the exteriors of Romanesque churches, particularly on corbels, ${ }^{50}$ I know of none inside a Spanish or French building, despite the frequent presence of other types of frank sexual imagery. ${ }^{51}$ The development of this new

49. For the Jaca capital, see Durliat, La sculpture romane de la route de Saint-Jacques, fig. 203; for San Isidoro, see Therese Martin, "Decorar, aleccionar, aterrorizar: escultura románica y gótica," in Real Colegiata de San Isidoro de León: relicario de la monarquía leonesa, ed. Constantino Robles García and Fernando Llamazares Rodríguez (León: Edilesa, 2007), 104-43, esp. 119. Weir and Jerman, Images of Lust, 98, note that "male apes are well-known for their frequent, and in extreme cases, continual masturbation," citing further examples in Iberia at San Martín de Unx, Arce, Aibar, Sos del Rey Católico, Loarre, and Rubiães (Portugal), as well as OloronSainte-Marie (France).

50. Masturbating men can be seen on Romanesque exteriors on both sides of the Pyrenees at such sites as Elines and Mansilla de la Sierra in northern Spain and Sévignac-Thèze in the French province of Pyrenées-Atlantiques. In addition, the website "Satan in the Groin" (http://www.beyond-the-pale.org.uk/satan3.htm) shows a capital from the castle chapel in Cheb, Czech Republic, that appears to represent a masturbating man.

51. For a discussion of Romanesque corbel imagery, see Nurith Kenaan-Kedar, Marginal Sculpture in Medieval France: Towards the Deciphering of an Enigmatic Pictorial Language (Brookfield, VT: Scolar Press, 1995), 1-76; and Weir and Jerman, Images of Lust. iconography, which kept the ape's open-legged squat but replaced the erect penis with the shaft of a crossbow, provided a framework for a visually acceptable reference to masturbation in the interior of a church.

The bestial vulgarity with which apes display themselves throughout Romanesque sculpture resonates in a pair of crossbowmen at the cathedral of Lescar. ${ }^{52}$ A capital in the north aisle features two crossbowmen who are identical in gesture: each naked figure squats in the characteristic position as, with muscles tightly flexed, he strains to span his two-foot weapon (Fig. 10a-b). Here the physiognomies of the crossbowmen have been differentiated so that the viewer can see both a deformed human (a) and a creature of simian aspect (b). ${ }^{53}$ Once again, the embodied gesture, nudity plus the arming of a crossbow, adds up to a being that is recognizable for its humanlike actions yet not a whole and upright man; this is not an honorable soldier but a brute who merits the scorn of Church and society. Rudolph's study of the Moralia in Job points most clearly to the link between brutish beasts and sexuality: "in yielding to the temptation of lust, rational human beings become like irrational animals, fixing their eyes on the lowest of things and following these as models." He cites Gregory the Great's assertion that true men are "unimpaired by the bestial stirring of the passions.... In turn, those who give way to carnal desire are no longer men but are called animals." ${ }^{54}$ As with their brothers-in-arms at the monastery of Moissac, the Lescar crossbowmen illustrate the bestiality to which man can be reduced when he gives in to the pollution of lust.

At Saint-Pierre in Moissac, a paired capital with a monstrous crossbowman centered on each long side of the basket is found in the more restricted monastic space of the cloister (Fig. 11a-b). ${ }^{55}$ Offering another variation on the theme, the

52. Françoise-Claire Legrand, La cathédrale de Lescar (Pau: Marrimpouey, 1970).

53. On the assimilation of deformity to monstrosity, see David Williams, Deformed Discourse: The Function of the Monster in Mediaeval Thought and Literature (Montreal: McGill-Queen's University Press, 1996); and Debra Higgs Strickland, Saracens, Demons, and Jews: Making Monsters in Medieval Art (Princeton: Princeton University Press, 2003).

54. Rudolph, Violence and Daily Life, 82, citing Gregory the Great, Moralia in Iob: S. Gregorii Magni Moralia in Iob 24:15-21, Corpus Christianorum, Series Latina 143-143B, ed. M. Adriaen (Turnhout: Brepols, 1985), 1198-1203.

55. For recent studies with extensive earlier bibliography, see Peter Klein, ed., Der mittelalterliche Kreuzgang: Architektur, Funktion und Programm (Regensburg: Schnell + Steiner, 2004), esp. Leah Rutchick, "Visual Memory and Historiated Sculpture in the Moissac Cloister," 190-211. 

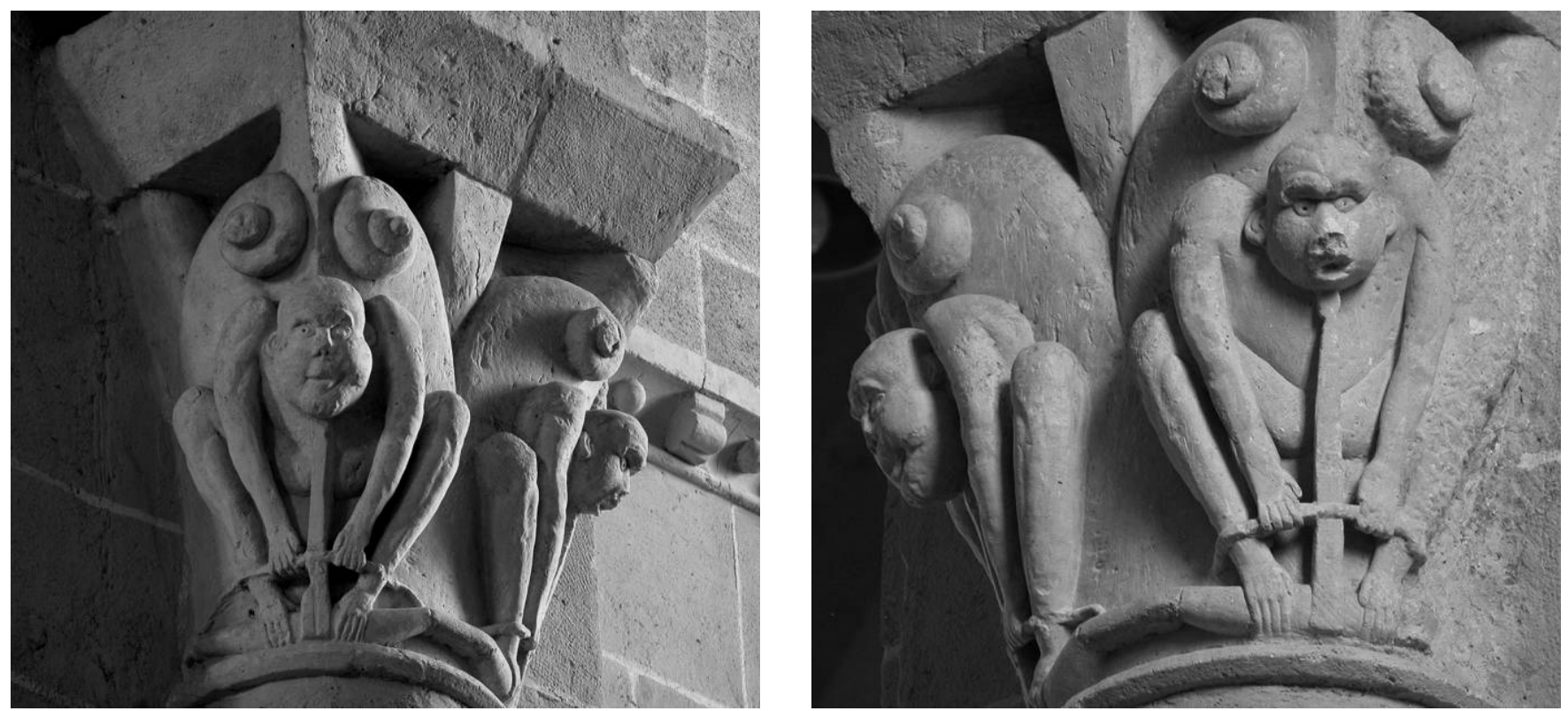

Figure 10a-b. Crossbowmen capital with human (left) and simian (right) figures, north aisle, cathedral of Lescar, first quarter of twelfth century (photos: author). See the electronic edition of Gesta for color versions of these images.

squatting hybrids of Moissac have outsized beasts' heads atop unclothed human bodies. ${ }^{56}$ Each strives to span his weapon while biting the points of two bolts in a composition that recalls the Toulousan capital (Fig. 6a); here, however, all components of the weapon are condensed in the central figures. Again we can glimpse a certain mordant humor or biting wit that treats the figures with contempt, while their too-large heads with animals' ears make clear their monstrous natures. At the corners and on the short sides of the capital are figures and animal masks that blow horns (Fig. 11a). These have been associated with drinking, music, and Islamic oliphants, ${ }^{57}$ but they also echo the common Romanesque iconography of trumpets being blown to signal the end of time and the commencement of Judgment, as does the figure embedded in a crenellation over Moissac's main portal. On this capital, in which oversized horns are held prominently between the legs of naked, squatting figures, the instrument reinforces the crossbowmen's connection to the act of masturbation.

One final representation of an unclothed crossbowman can be seen on a portal capital from San Pedro de las Dueñas, now housed at the Museo Arqueológico Nacional in Madrid

56. For monstrous figures that have been interpreted as a rejection of the flesh and a desire for purity on the part of the religious, see Wirth, L'image à l'époque romane, 260-63.

57. Inés Monteira Arias, El enemigo imaginado: la escultura románica hispana y la lucha contra el Islam (Toulouse: CNRSUniversité de Toulouse-Le Mirail, 2012), 304-19.
(Fig. 12).$^{58}$ The Dueñas capital, probably once at the original entrance to the chapter room, was placed directly before the eyes of the nuns as they passed through the doorway for their daily gathering. Its composition was inspired by the figure at San Isidoro (Fig. 1a), as is the case for much of the decoration at this female monastery. ${ }^{59}$ Rather than being flanked by sexualized women, however, this diminutive, naked crossbowman presides over a pride of lions, in a curving composition also drawn from examples at San Isidoro. Here the unbridled passions often read into Romanesque representations of this multivalent beast seem to have been tamed. ${ }^{60}$ At both Dueñas and Moissac, the claustral context of the sculpture would have reduced the crossbowmen's audience mainly to the community and their elite patrons. The multivalence of

58. José Luis Senra, "San Pedro de las Dueñas," in Enciclopedia del Románico en Castilla y León: León (Aguilar de Campoo: Fundación Santa María la Real, Centro de Estudios del Románico, 2002), 5:72738 , at 734 .

59. Manuel Gómez-Moreno, Catálogo monumental de España: provincia de León (Madrid: Ministerio de Instrucción Pública y Bellas Artes, 1926), 1:358-61; and John Williams, "La arquitectura del camino de Santiago," Compostellanum 29 (1984): 239-65.

60 . For the many meanings that have been given to the lion, see Peter Bloch, "Löwe," in Lexikon der christlichen Ikonographie (Freiburg im Breisgau: Herder, 1971), 3:112-19; and François Amy de la Bretèque, "Le motif du lion dans l'art et la littérature du Moyen-Âge: recherche sur la mentalité et la civilisation" ( $\mathrm{PhD}$ diss., Université de la Sorbonne, Paris III, 1986). 

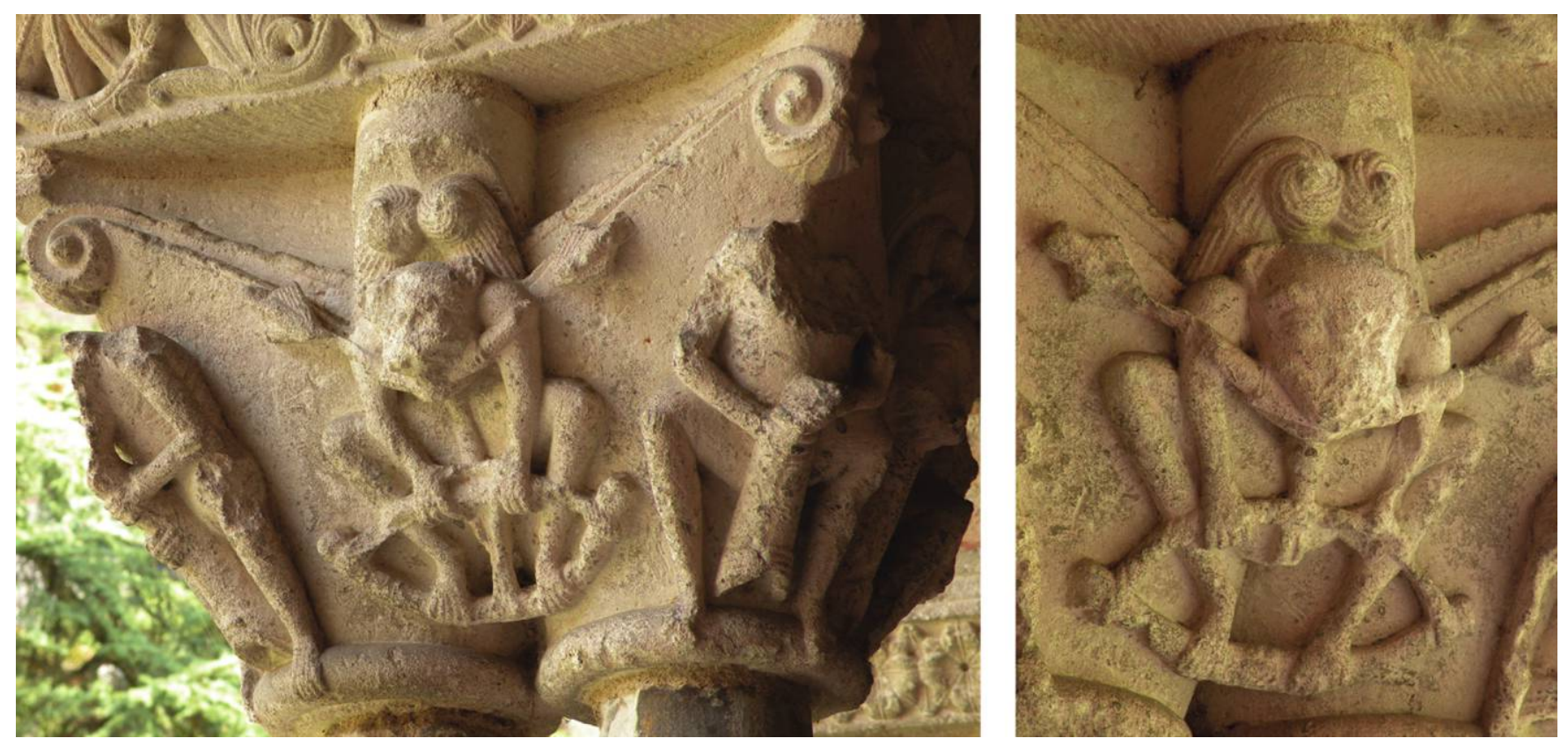

Figure 11a-b. Crossbowmen on each long side of paired capital, cloister, Saint-Pierre, Moissac, first quarter of twelfth century (photos: author).

monstrous imagery within Romanesque cloisters has recently been addressed by Mary Carruthers, who asks,

And what experience do they provoke, these scenes of vigorous demonic activity, in the context of claustral study or liturgical prayer? Varietas, in the form of laughter (ridiculousness) or fearfulness (devils' torments) or admiratio (wonder at what is strange) for the bizarre and unexpected (which the monsters provide). They surprise us-they did then, they do now. Their very diversity and discord shocks one from the temptation to taedium, and its companions, fastidium and satietas. ${ }^{61}$

Depending on its setting, then, this new iconography offered adaptability to the needs of both lay and religious viewers. It would seem that all was in order for a long-lasting image to spread byond the initial sites, but this was not to be.

So, whether the images were directed at monastic eyes or diverse audiences, what links these varying representations of the unclothed crouching crossbowman? Historical context, both time and place, provides a clue. This iconography accords with certain aspects of the early twelfth-century sources that mention the crossbow itself. To grasp the role that this figure was made to play in Romanesque sculpture, it

61. Mary J. Carruthers, The Experience of Beauty in the Middle Ages (Oxford: Oxford University Press, 2013), 148. is essential to understand how the weapon appears in written evidence from the first half of the century. Most important is the oft-quoted anathema handed down by Innocent II in 1139 at the Second Lateran Council. This papal proscription deserves to be treated with greater nuance, as it has tended to be uncritically repeated throughout the historiography as though referring to the crossbow alone. In Canon 29, the pope outlawed the use of such hateful weaponry among the faithful (war against the infidel was, of course, a different matter): "Under pain of anathema, we forbid that that deadly art, hateful to God, of crossbowmen and archers be practiced against other Christians and Catholics." ${ }^{62}$ My emphasis highlights the fact that the pontiff was concerned with not one but two types of long-range weapons, for both broke the rules of fair play in hand-to-hand combat and thus had

62. "Artem autem illam mortiferam et Deo odibilem ballistariorum et sagittariorum adversus Christianos et Catholicos exerceri de cetero sub anathemate prohibemus." J. D. Mansi, Sacrorum Conciliorum Nova et Amplissima Collectio (Graz: Akademische Druck- u. Verlagsanstalt, 1961), 21:533. See also Charles Joseph Hefele, Histoire des conciles d'après les documents originaux (Paris: Letouzey, 1913), 5:455; Paul Fournier, "La prohibition par le Ile Concile de Latran d'armes jugées trop meurtrières (1139)," Revue générale du droit international public 23 (1916): 47179; H. J. Schroeder, Disciplinary Decrees of the General Councils: Text, Translation and Commentary (St. Louis: Herder, 1937), 195213; and R. Foreville, Latran I, II, III et Latran IV (Paris: L'Orante, 1965), 89, 194, 356.

$156:$ Gesta $\quad$ v54n2, Fall 2015 


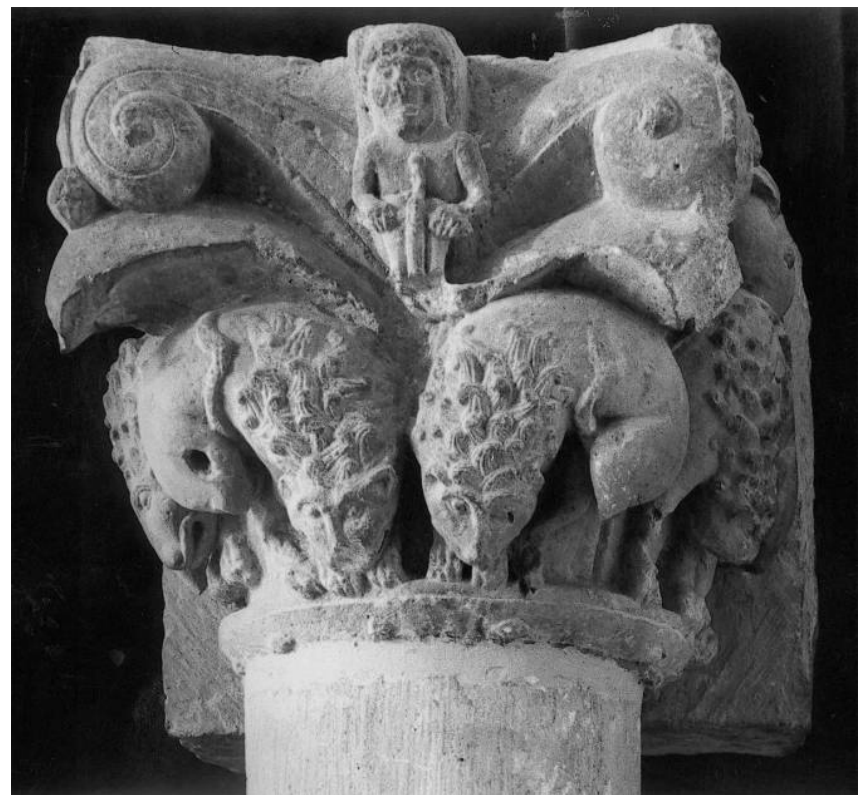

Figure 12. Crossbowman capital, probably originally on chapter room portal, San Pedro de las Dueñas, first quarter of twelfth century, now Madrid, Museo Arqueológico Nacional, N.I. FD/P/02874 (photo: Museo Arqueológico Nacional).

the potential to be subversive. ${ }^{63}$ Sven Ekdahl made the astute observation: "Behind this, surely, lay the fear that the social order might break down if these simple but effective weapons became widespread among the lower classes and thus might threaten the superiority of the nobility and the Church." ${ }^{4}$ The regular bow was already prevalent at this time, and crossbow use was rapidly on the rise. Scholars have seized on the papal anathema to explain the rare visual representations of the crossbow, but this particular condemnation might be better applied to the omnipresent image of the archer. Whether portrayed as man or ape, soldier or Sagittarius, carved figures armed with standard bows can be found throughout all lands where Romanesque sculpture was made. The very ubiquity of the archer, however, makes a study of that figure less tell-

63. Helen Nicholson, Medieval Warfare: Theory and Practice of War in Europe, 300-1500 (Houndmills: Palgrave Macmillan, 2004), succinctly notes (99-100) that "by the twelfth century the bow, as a 'peasant's weapon' which could be operated at a safe distance from the enemy, was looked down upon by knights, even though they all learnt how to use it." A suggestive semantic relationship is briefly sketched in G. D. Gaunt, D. J. F. Hill, and E. McEwen, "Linguistic Associations between Sin and Archery," Journal of the Society of Archer-Antiquaries 17 (1974): 17-18.

64. Sven Ekdahl, "Horses and Crossbows: Two Important Warfare Advantages of the Teutonic Order in Prussia," in The Military Orders, vol. 2, Welfare and Warfare, ed. Helen Nicholson (Aldershot: Ashgate, 1998), 119-51, at 137. ing than one focused on the seldom-represented crouching crossbowman. ${ }^{65}$ His humiliating, squatting appearance at just this time and in only these places enables us to comprehend a new iconography, while a study of military history helps to explain why the image failed to thrive.

Although neutral references to crossbows had appeared in Western Christian written documentation from at least the late tenth century, such as the chronicle of Richer (d. ca. 998), which mentions both archers and crossbowmen ("sagittarii cum arcubus et balistis") under the command of King Lothair of Lotharingia about $985,{ }^{66}$ pointedly critical statements emerge in ecclesiastical sources during the first half of the twelfth century. An example is the chronicle completed about 1117 at the Leonese royal monastery of Sahagún, on which the female monastery of San Pedro de las Dueñas depended. In this Crónica anónima, the crossbow makes an appearance in the hands of a lawless ruffian. ${ }^{67}$ The abbot of Sahagún had traveled to Dueñas to celebrate a funeral mass for one of the nuns, accompanied, we are told, by the anonymous scribe who wrote the chronicle and acted as eyewitness to the harrowing events. When the monastery came under attack, the rebellious townspeople, led by a nobleman called Giraldus el Diablo (the Devil), attempted to break down the doors and then scaled the precinct walls to enter the church itself.

65. Monteira Arias, El enemigo imaginado, 369-95. Published directly from the author's 2010 dissertation, this 850 -page book with a separate $\mathrm{CD}$ of more than one thousand images catalogues an impressive number of Romanesque figures and a startlingly all-encompassing range of iconographic types, among them archers, crossbowmen, and centaurs. She proposes an overarching hypothesis that attempts to explain (ultimately unsuccessfully) much of the Romanesque sculpture in Spain and France as a polemical visualization of the battle against Islam. Monteira Arias correctly points to the place of the crossbow within chansons de geste from the late twelfth and thirteenth centuries (375-76), but the weapon does not appear to form part of any literary tradition from the beginning of the twelfth century, contemporary with the Romanesque sculptures that are the focus of this article. I am grateful to Alberto Montaner and Francisco Bautista Pérez for consultations on questions of twelfth-century literature.

66. Claude Gaier, "Quand l'arbalète était une nouveauté: réflexions sur son rôle militaire du Xe au XIIIe siècle," Le Moyen Âge 99 (1993): 201-29, esp. 210-12; see Richer of Saint Rémi, Histories, ed. and trans. Justin Lake (Cambridge, MA: Harvard University Press, 2011), 2:168. See also Arthur G. Credland, "The Crossbow and the Law from the Dark Ages to the Present," Journal of the Society of Archer-Antiquaries 33 (1990): 51-64. Credland notes (52) "the ban on those in holy orders taking charge of crossbowmen: 'Nullus quoque clericus rotariis aut balistaris aut huismodi viris sanguinum praeponantur,'” citing Johann Jacob Hofmann, Lexicon Universale (Basel: Widerhold, 1677), Concilium Lateran IV, can. 18.

67. Antonio Ubieto Arteta, ed., Cronicas anónimas de Sahagún (Zaragoza: Anúbar, 1987). The early twelfth-century text survives only in a fourteenth-century copy. 
And then the armed and shield-bearing men climbed up onto the roof and leapt down into the cloister. From among them, a crossbowman [un ballestero de arco], breaking through the nuns' choir, as he could see the abbot standing before the holy altar, extended his bow with the bolt, wanting to shoot him in the back with it. And as death came flying quickly with the bolt, one of the virgins, with her sleeve extended, received and stopped the flying bolt, which fell to the ground without causing a single wound. ${ }^{68}$

In this recounting, the virginal purity of the religious woman becomes an effective defense against the terrible weapon in the hands of a pillager, whose transgressive violence breaks not only the sanctity of the nuns' cloister but also the sanctuary of the church itself, with the aim of shooting an abbot in the back. The vile nature of the crossbowman, as singled out by this early twelfth-century churchman, could hardly be summed up more clearly.

It seems that ecclesiastical writers of the early twelfth century felt the need to discredit the crossbow and those who wielded it by making it the weapon of choice in tales of unlawful violence. Another such chronicler was Orderic Vitalis (d. 1142), who relates the treacherous use of a crossbow by Juliana, an illegitimate daughter of King Henry I of England, in her doomed rebellion against her father: ${ }^{69}$

In the same year [1119] Eustace of Breteuil, the king's son-in-law, ... sent his wife Juliana, who was the king's daughter by a concubine, to Breteuil, and provided her with the knights necessary to defend the castle. ... The provident king ... besieged the castle in which his impudent daughter had shut herself up. Juliana was now extremely anxious and unsure what to do. She was certain that her father, knowing the situation, had arrived in a rage against her and would not raise the siege now in place around the castle until he had triumphed. Nevertheless, as Solomon says, "There is no wickedness like a woman's wickedness" [Ecclus. 25:26], and in the end, plotting to raise her hand against the Lord's anointed, she treacherously asked to speak to her father.

68. Ibid., 95. For further analysis of this event in the documentary record, see William R. Moore, "Religious Language and the Construction of Royal Power: Leon, 1037-1126” (PhD diss., Columbia University, 2009), 313-16.

69. Henry I (r. 1100-35) had some twenty illegitimate children. See Judith Green, Henry I: King of England and Duke of Normandy (Cambridge: Cambridge University Press, 2006), appendix 1, "Inheritances and Family Trees," 322-23.

$158:$ Gesta v54n2, Fall 2015
The king, ignorant of the woman's trick, came to meet with her, while his accursed child hoped to murder him. She had a crossbow already cocked and shot a bolt at her father, but God protected him and she missed. The king immediately ordered that the castle drawbridge be destroyed, so that no one could enter or leave. Juliana, seeing that she was completely surrounded and that no one was going to help her, surrendered the castle to the king, but could not persuade him to allow her free departure. Indeed by the king's order she was forced to leap down from the top of the wall, with no bridge or support, and fell ignominiously, with bare buttocks, into the depths of the moat. This happened at the beginning of Lent, in the third week of February, when the castle moat was full to overflowing with winter rains, and the frozen waters naturally struck numbing cold into the tender flesh of the fallen woman. The unlucky female warrior shamefully extracted herself from the predicament as best she could. ${ }^{70}$

It is telling that the weapon Orderic Vitalis chose to place in Juliana's hands in 1119 for her failed attempt at the dually transgressive act of regicide and patricide is the same one given to the rebels under Giraldus el Diablo just two years earlier by the anonymous chronicler of Sahagún. Both protagonists were denounced for their ignoble endeavors to subvert the proper ordering of society; both were converted into shameful exempla, their stigma made concrete through the use of this weapon. That the crossbow was deliberately introduced by Orderic to increase Juliana's infamy becomes clear when we compare his version of the tale with that by Robert de Torigny in the Gesta Normannorum ducum. The latter related Juliana's story without the detail of the crossbow, although he retained the idea of her faithlessness, blaming her for her husband's loss of Breteuil because "his wife Juliana, the bastard daughter of King Henry, arrogantly and foolishly expelled [the king's] wardens from the castle of Breteuil, against the king's wishes and her own fealty." ${ }^{11}$

Indecency underlies Orderic's tale of the illegitimate daughter's revolt, in a way that parallels the concept of shameful violence and sexuality behind the Romanesque crouching crossbowmen. In Juliana's hands, the crossbow was an effective symbol of subversion because of its recognized potential to disrupt societal norms. And the effect was multiplied when it was wielded by a woman, whose comeuppance was

70. Marjorie Chibnall, ed. and trans., The Ecclesiastical History of Orderic Vitalis (Oxford: Clarendon Press, 1978), 4:212-14.

71. Elisabeth M. C. van Houts, ed. and trans., The Gesta Normannorum Ducum of William of Jumièges, Orderic Vitalis, and Robert of Torigni (Oxford: Clarendon Press, 1992), 1:290. 
therefore portrayed by Orderic Vitalis as doubly revealing. In the perceptive analysis of Leonie Hicks,

Both Juliana's garrison inside the castle and Henry's army outside it watched the lady of Breteuil fall, stripped of dignity, from the battlements into the moat. These actions demonstrated publicly that she was a woman through the exposure of her genitals, and, more to the point, a woman who had failed. ... Juliana, the lady of Breteuil, fell, both figuratively and literally diminishing her status. Her public shaming struck at the heart of medieval ideas about the weak and treacherous nature of women, prone to succumb to temptation and drag good men down with them. ${ }^{72}$

In this scene, Juliana is depicted as an unnatural daughter who would destroy social order by killing her lord and father, cast in a humiliating and sexually exposed position as a result of her dishonorable action with the crossbow.

In word and image, then, the Church sought to discredit the crossbow in the early twelfth century by shaming those who wielded it. But it was a losing battle: the weapon gained in popularity and became standard gear among soldiers and townspeople alike by midcentury. Its growing currency and concomitant normalization among the laity are reflected in the lexicon of medieval León-Castile. A search through the Index verborum of medieval Leonese documentation, for example, finds no instance of the word "crossbowman" in the first half of the twelfth century. ${ }^{73}$ It makes its appearance in 1169 in a charter from the monastery of Sahagún, where one "Perronet balestero" had sufficient status to be included among the signatories confirming the sale of a farm between two couples, small landowners within the territory of Sahagún. ${ }^{74}$ For the documentary collection of the cathedral of León, the first appearance of "crossbowman" is even later. In 1211 "Tomas balestero" figures in the list of individuals who confirmed an exchange of lands between the bishop of León and a priest. ${ }^{75}$ Throughout the thirteenth century, the role of

72. Leonie V. Hicks, "Magnificent Entrances and Undignified Exits: Chronicling the Symbolism of Castle Space in Normandy," Lournal of Medieval History 35, no. 1 (2009): 52-69, at 66-67.

73. I am grateful to Isabel Alfonso for suggesting that I consult José María Fernández Catón, Index verborum de la documentación medieval leonesa, vols. 1-2, Monasterio de Sahagún (857-1300), and vols. 3-4, Archivo Catedral de León (775-1300) (León: Centro de Estudios e Investigación “San Isidoro," 1999 and 2002).

74. José Antonio Fernández Flórez, Colección diplomática del monasterio de Sahagún, vol. 4, 1110-1199 (León: Centro de Estudios e Investigación “San Isidoro," 1991), doc. 1364.

75. José María Fernández Catón, Colección documental del archivo de la catedral de León, vol. 6, 1188-1230 (León: Centro de crossbowmen in armies and town militias only increased, as did the presence of the weapon in the written record, where accounts could now be positive or negative according to the interests of the author.

This shift in chronology and meaning is evident in the final sculpture of a crouching crossbowman, who differs from all the rest in being later by at least a decade and, most significantly, in being clothed. He appears on the facade of San Quirce (Fig. 13), where, in an earlier phase of construction, the masturbating ape from the apse of the church gave a clue to the essence of the crossbowman's crouch (Fig. 8b). On San Quirce's north portal, the relief plaques bear physical evidence in support of the theory that they were originally sculpted for the west facade around the $1130 s .{ }^{76}$ Once these plaques were moved to the north portal, the crossbowman was placed in conjunction with two other figures: SAMSON FORTISSIMVS, as the titulus reads (with whom the crossbowman may originally have been intended to be grouped), and a centaur with the inscription SAGITARVS, ${ }^{77}$ who has just released an arrow that pierces the crossbowman's side, demonstrating that these two figures were certainly meant to be viewed together. Squatting in the familiar pose, with two feet pressing down on the bow while he draws the string up in preparation for locking and firing, this crossbowman's movements are abruptly halted by the centaur's enormous arrow penetrating his torso (Fig. 14). The sculptor here clearly represented an arrow, with the large pointed head and extensive fletching that distinguish it from a crossbow's bolt. ${ }^{78}$ Although the figure's tunic rises as he bends his legs to span the bow, cape flying up in response to the action, this crossbowman's nakedness is not revealed.

At San Quirce, the associated representations of centaur and crossbowman provide a complete illustration of the 1139 papal prohibition against the dual "deadly art" that kills from a distance. The censure here would seem to be against unlawful violence alone, without the element of shameful sexuality

Estudios e Investigación “San Isidoro," 1991), doc. 1820.

76. Close on-site examination of the framing devices around the figures shows that the stonework of the previously plain north facade was cut down in order to accommodate the later insertion of sculpture. In addition, as Amanda Dotseth has observed, at least one plaque has lost part of its inscription when it was trimmed to fit the new setting. I am grateful to her for discussing her work in progress with me. San Quirce had traditionally been dated about 1147, the year in which a college of canons was established in the preexisting monastery. Dotseth, however, has shown that date to be too late and rightly places this sculpture in the 1130s.

77. Sagittarius, of course, means archer, whether lowercased for a soldier armed with a bow or capitalized for the zodiac symbol.

78. For images of bolts, see the examples from Santiago, Toulouse, and Moissac in Figs. 5, 6a, and 11a-b. 


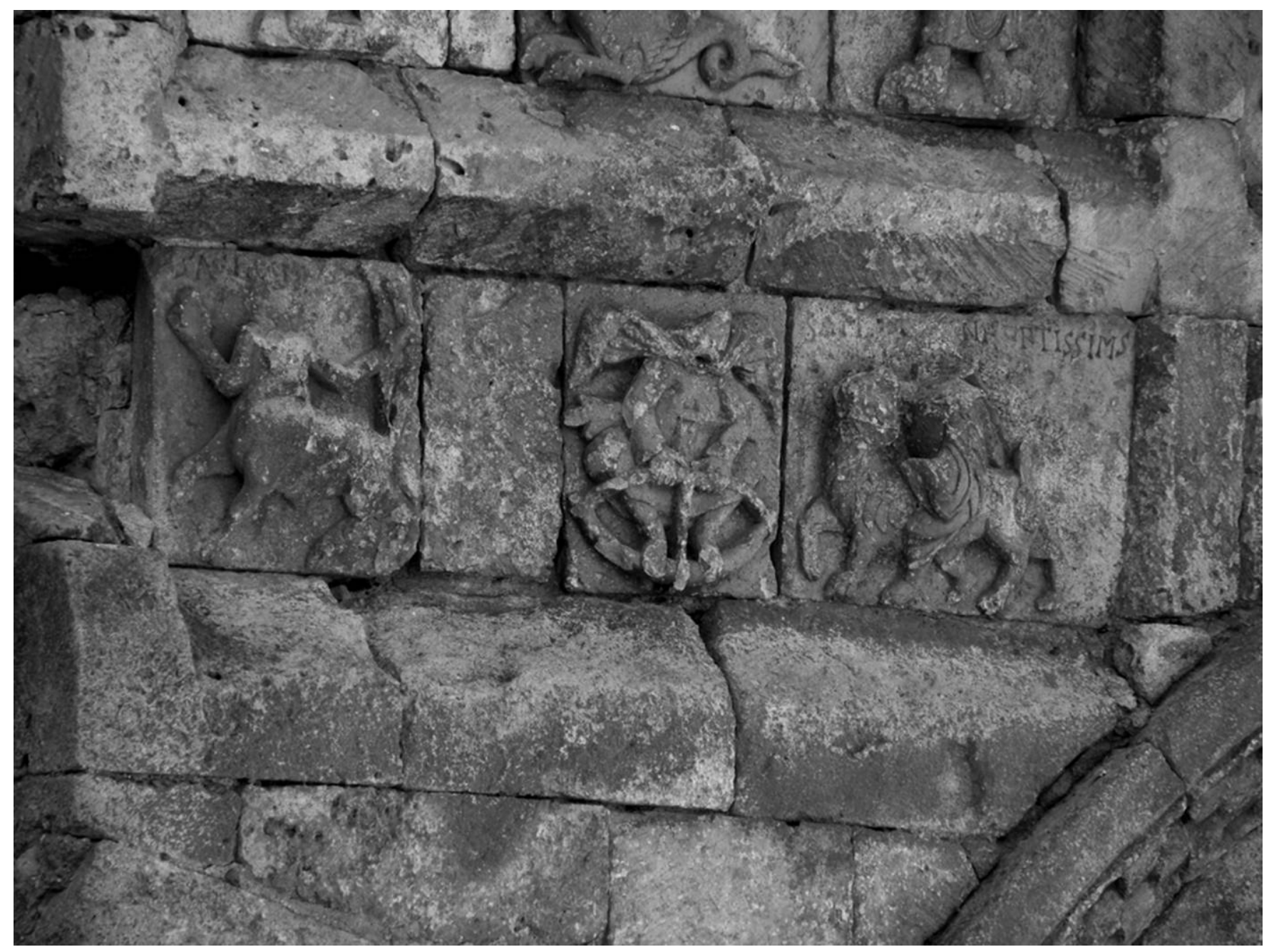

Figure 13. Crossbowman, Samson, and Sagittarius plaques, originally on west facade, now on north portal, San Quirce, ca. 1130s (photo: author). See the electronic edition of Gesta for a color version of this image.

present in the nude examples. This crouching crossbowman has been adapted to the changing times, but the fact that he is the last of his line also indicates that clothing the deviant creature was not a successful shift in iconographic terms. While the figure's pose is prescribed by his two-foot weapon, his clothing communicates that he is fully man (evident despite the loss of his head), in contrast to the earlier objects of humiliation, but even more immediately in comparison with the hybrid nature of the centaur with whom he is here paired.

By about 1200, when the iconography of the crouching crossbowman had long been abandoned, images of the weapon itself appear with increasing frequency in scenes of battle or the hunt, as, for example, on a capital from the upper cloister at Santo Domingo de Silos (Fig. 15). ${ }^{79}$ The

79. Justo Pérez de Urbel, El claustro de Silos, 3rd ed. (Burgos: Institución Fernán González, 1975), 204-6; and Elizabeth Valdez del sculpture shows two hunting crossbowmen, one aiming at a tree while the other spans his weapon with a single foot in the stirrup. Both are dressed elegantly, a sharp contrast with the crotch-displaying crossbowmen of the early twelfth century. Later, when Alfonso X "the Learned" of Castile-León (r. 1252-84) was commissioning chronicles, songs in praise of the Virgin, and books of law and entertainment, the crossbow appeared in the prologue to his Book of Games for its place in mounted games of skill, as an element of God-given happiness in the workaday world. ${ }^{80}$ Such a positive reading had been far from the norm at the turn of the twelfth century.

Álamo, Palace of the Mind: The Cloister of Silos and Spanish Sculpture of the Twelfth Century (Turnhout: Brepols, 2012), 311-13.

80. Prologue as transcribed by Sonja Musser Golladay, "Los Libros de Acedrex Dados e Tablas: Historical, Artistic and Metaphysical Dimensions of Alfonso X’s Book of Games" (PhD diss., University

$160:$ Gesta $\quad$ v54n2, Fall 2015 


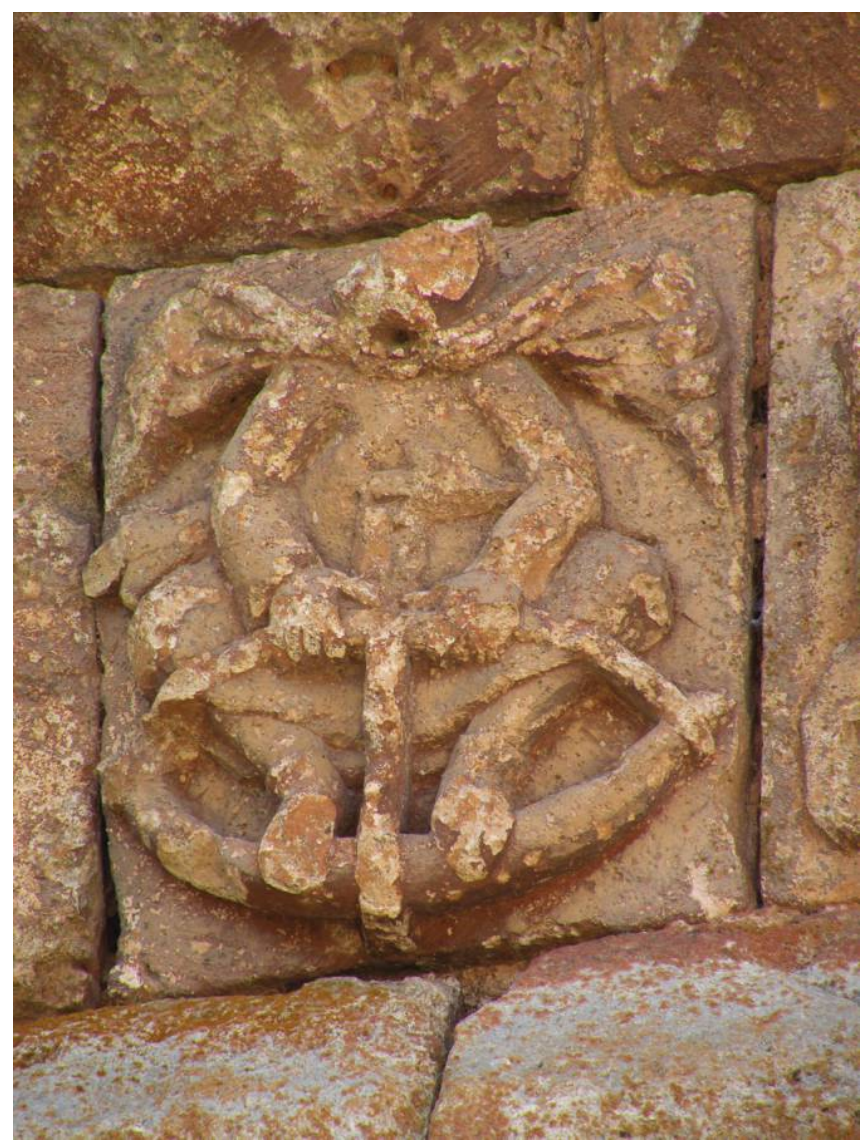

Figure 14. Crossbowman, originally on west facade, now on north portal, San Quirce, ca. 1130s (photo: author).

Having accounted for the chronological limitations of the crouching crossbowman iconography, how can we explain its geographic boundaries? Romanesque imagery in northern Spain and southern France shared much visual vocabulary, carried in the memories or model books of masons who traversed these territories. Still, why should the representation be limited to these areas, given that Romanesque sculpture representing the castigation of lust or ire (the latter vice another type of misdirected violence) was so frequently seen in other forms throughout all regions with figural imagery ${ }^{21} \mathrm{My}$ research suggests that the presence of the crouching crossbowman at these sites was inspired by contacts with Muslims, not as a polemic against Islam per se but rather because of

of Arizona, 2007), 1239-40: "Por que toda manera de alegria quiso dios que ouiessen los omnes en si naturalmientre por que pudiessen soffrir las cueytas \& los trabaios quandoles uiniessen. ... Los unos en caualgando assi como boffordar \& alançar \& tomar escud \& lança \& tirar con ballesta o con arco." Emphasis mine.

81. Many Romanesque capitals with scenes of lust and/or violence are illustrated in Jesús Herrero Marcos, La lujuria en la iconografía románica (Palencia: Cálamo, 2011).

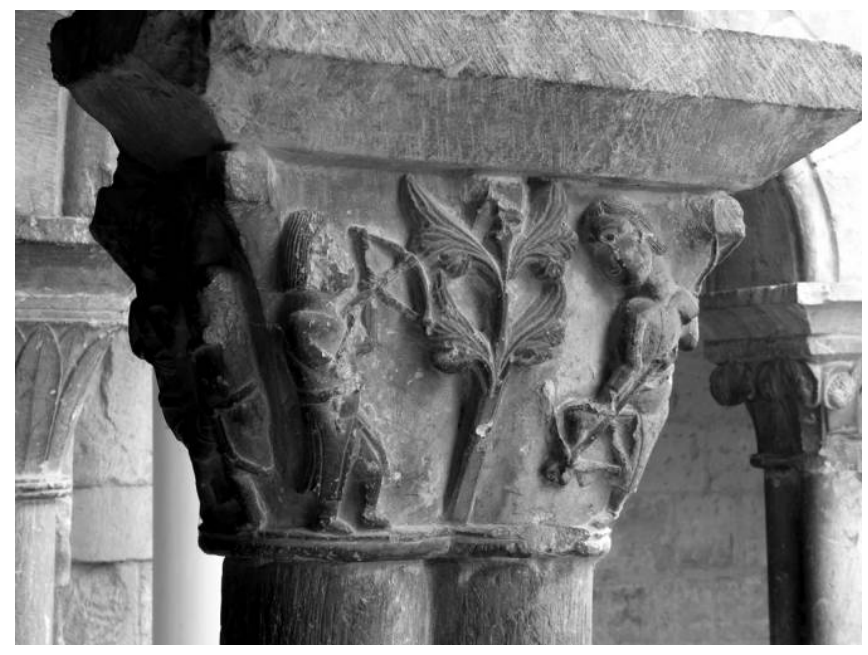

Figure 15. Crossbowmen hunting, upper cloister, Santo Domingo de Silos, ca. 1200 (photo: author). See the electronic edition of Gesta for a color version of this image.

earlier familiarity with the weapon and the scorn-inducing posture necessary to arm it. The evidence for this unexpected conclusion, derived from both documentary and archaeological sources, is small but significant. ${ }^{82}$ Drawing together decades of research, David Nicolle concluded:

The crossbow was used much more widely in the medieval Islamic world than is generally realized. It was adopted at a remarkably early date and appeared in the same forms as would be used in Western Europe.... During the tenth to twelfth centuries the crossbow was largely restricted to siege and naval warfare in the Islamic Middle East, Maghrib and al-Andalus.... The qaws al-rijl "foot bow" and qaws al-rikab "stirrup bow" had been used by the Fatimid army of Egypt during the later eleventh and first half of the twelfth century, being lighter and smaller forms of crossbow which could be spanned, shot and presumably also carried by one man. As such they were the same as the most common forms of crossbow in medieval Europe, though having been adopted at a slightly earlier date. ${ }^{83}$

82. Bachrach, "Crossbows for the King," 117, shows the continuation of this connection in the persons of Peter Sarazcenus and Benedict Maurus, crossbowmakers in England at the turn of the thirteenth century.

83. David Nicolle, Crusader Warfare, vol. 2, Muslims, Mongols and the Struggle against the Crusades, 1050-1300 AD (London: Hambledon Continuum, 2007), 182-85. Nicolle traces the complex history of the Arabic terminology in "Medieval Warfare: The Unfriendly Interface," Journal of Military History 63, no. 3 (1999): 57999 , at 593n5, concluding that "all that can be said with certainty 
Significantly, archaeology not only confirms the textual references but also testifies to the crossbow's early expansion in Islamic Iberia. Two crossbow nuts made from bear bone were excavated from Islamic areas of present-day Portugal, one from the tenth or eleventh century and the other from the eleventh or first half of the twelfth. ${ }^{84}$ This type of evidence has not been collected and analyzed for its significance in terms of the multicultural weapon history of the Iberian peninsula, much less recognized for its role in the development of Romanesque iconography.

There can be little doubt that the increasing Christian dominance of the peninsula from the second half of the twelfth century onward led to a change in the ways Islamic warriors would come to be portrayed in Castilian imagery. ${ }^{85}$ In the first quarter of the twelfth century, however, when the crossbowman sculpture was developed, such a stereotyped image of Muslims was not yet a common part of the cultural milieu. In the kingdom of León-Castile, where all the Spanish examples are found, this period encompassed the end of the reign of Alfonso VI (r. 1065/72-1109) and all of his daughter Urraca's rule (1109-26); its political history cannot be generalized as either convivencia ${ }^{86}$ or crusade $e^{87}$ but, rather, was a type of uneasy coexistence somewhere in between. ${ }^{88}$ Internal insta-

is that the weapon did not arrive from Western Europe." For the early use of crossbows in Islamic societies, see also Gaier, "Quand l'arbalète était une nouveauté," $211 \mathrm{n} 14$.

84. I am grateful to Marta Moreno-García for wide-ranging discussions on bio-archaeology and for bringing these examples to my attention. See Mário Jorge Barroca and João Gouveia Monteiro, eds., Pera Guerrejar: armamento medieval no espaço português (Palmela: Câmara Municipal, 2000), nos. 117-18. See also Rafael Azuar Ruiz, Denia islámica: arqueología y poblamiento (Alicante: Instituto de Cultura "Juan Gil-Albert," Diputación Provincial de Alicante, 1989), for excavations of twelfth-century crossbow nuts and quarrels in Islamic Denia.

85. Strickland, Saracens, Demons, and Jews, esp. 157-210.

86. For the concept of convivencia as "the source of growing unease among the historians of medieval Spain," see Maya Soifer, "Beyond Convivencia: Critical Reflections on the Historiography of Interfaith Relations in Christian Spain," Journal of Medieval Iberian Studies 1, no. 1 (2009): 19-35, esp. 20. For the thirteenth century, see also Jerrilynn D. Dodds, María Rosa Menocal, and Abigail Krasner Balbale, The Arts of Intimacy: Christians, Jews, and Muslims in the Making of Castilian Culture (New Haven: Yale University Press, 2008).

87. R. A. Fletcher, "Reconquest and Crusade in Spain, c. 10501150," Transactions of the Royal Historical Society, 5th ser., 37 (1987): $31-47$, notes (43) that we really only find "incipient crusading consciousness in Spain from about the third decade of the twelfth century." See also the works cited in note 97 below.

88. Bernard F. Reilly, The Kingdom of León-Castilla under Queen Urraca, 1109-1126 (Princeton: Princeton University Press, 1982; also Library of Iberian Resources Online, http://libro.uca.edu /urraca/urraca.htm); idem, The Kingdom of León-Castilla under bility in the early years of Urraca's reign kept her attention focused on maintaining the independence of her kingdom from that of her husband, Alfonso I of Aragón (r. 1102-34). ${ }^{89}$ Further, her queenship coincided with a time in which the unified might of the Almoravids had weakened following the death of Yusuf ibn Tashufin in 1106 and before the arrival of another strong Berber dynasty, the Almohads, beginning in the $1140 \mathrm{~s} .{ }^{90}$ In northern Iberia at the beginning of the twelfth century, the political situation did not lend itself to the type of anti-Islamic imagery that would develop some time after the iconography of the crouching crossbowman had been discarded, when escalating attacks on the Almohads by the Christian forces under Urraca's son Alfonso VII (r. 1126-57) saw a parallel rise in anti-Muslim sentiment. ${ }^{91}$ John Williams has identified the 1140s as a time of crusading imagery during which there was a surge in the "general and longstanding predisposition to see Saracens as sexually indulgent." ${ }^{22}$ However, if the crouching crossbowman had been tied primarily to the

King Alfonso VI, 1065-1109 (Princeton: Princeton University Press, 1988; also Library of Iberian Resources Online, http://libro.uca.edu /alfonso6/alfonso.htm); and Andrés Gambra, Alfonso VI: cancillería, curia e imperio, 2 vols. (León: Centro de Estudios e Investigación "San Isidoro," 1998).

89. In addition to Reilly, Kingdom of León-Castilla under Queen Urraca, see Irene Ruiz Albi, La reina doña Urraca (1109-1126), cancillería y colección diplomática (León: Centro de Estudios e Investigación "San Isidoro," 2003); Therese Martin, "The Art of a Reigning Queen as Dynastic Propaganda in Twelfth-Century Spain," Speculum 80, no. 4 (2005): 1134-71; and María del Carmen Pallares and Ermelindo Portela, La reina Urraca (San Sebastián: Nerea, 2006). For iconography that responded to this political instability, see José Luis Senra, "Rebellion, Reconciliation, and a Romanesque Church in León-Castile (c. 1109-1120)," Speculum 87, no. 2 (2012): 376-412.

90. Bernard F. Reilly, The Kingdom of León-Castilla under King Alfonso VII, 1126-1157 (Philadelphia: University of Pennsylvania Press, 1998); and Maribel Fierro, The Almohad Revolution: Politics and Religion in the Islamic West during the Twelfth-Thirteenth Centuries (Farnham: Ashgate/Variorum, 2012).

91. For the larger history of how medieval Christians viewed Muslims, see the important studies by John V. Tolan, esp. Saracens: Islam in the Medieval European Imagination (New York: Columbia University Press, 2002), 70: "By the end of the twelfth century, European writers had created the essential portrayals of Islam that would be elaborated upon, reworked, and deployed for different purposes for centuries to come"; and idem, Sons of Ishmael: Muslims through European Eyes in the Middle Ages (Gainesville: University Press of Florida, 2008).

92. John Williams, "Generationes Abrahae: Reconquest Iconography in León,” Gesta 16, no. 2 (1977): 3-14, esp. 8-11; see also the Spanish translation of his article with postscript in El timpano románico: imágenes, estructuras y audiencias, ed. Rocio Sánchez Ameijeiras and José Luis Senra Gabriel y Galán (Santiago de Compostela: Xunta de Galicia, 2003), 155-80, esp. 177-80; and Tolan, Saracens, 147-69.

$162:$ Gesta $\quad$ v54n2, Fall 2015 
idea of Islamic sexuality, we would expect to find the figure represented in greater numbers after the middle of the twelfth century; instead, by that time it had faded away. Had it been a product of the later Middle Ages, we might attribute its creation to the all-encompassing environment of religious polemic, in which Muslim and Jewish men were feminized and denigrated as submissive, as Louise Mirrer has shown for the thirteenth through fifteenth centuries. ${ }^{93}$ This image, however, had nothing to contribute to the anti-Islamic discourse that strengthened as the twelfth century advanced. Despite the possibility that the crouching crossbowman's original inspiration came from witnessing the actions of Muslim archers, the absence of this iconography after the 1130s indicates that it did not have an essentially anti-Islamic meaning. The figure spoke of and to those within the Church, not those outside it.

While contact between cultures, and with it an early familiarity with this on-the-rise weapon, may have provided the initial visual spark that led to the creation of a new iconography, rapidly changing arms technology caused the image to lose its potency as a symbol of subversion of societal norms. Had the development of the crossbow not progressed beyond the two-foot variety, this iconography also might have multiplied throughout other regions. As it was, usage of the various forms of the weapon escalated through the twelfth century, culminating in an unstoppable expansion of the crossbow within the armies of both Muslims and Christians. ${ }^{94}$ While we have seen the attempted rejection of the crossbow by churchmen in both written and visual evidence, secular rulers encouraged its use. The result is clear in the Chronica Adefonsi imperatoris (ca. 1145), which notes the presence of Iberian crossbowmen on both sides of the religious divide. ${ }^{95}$

Another great army of Moabites and Arabs, sent by King Tashufin of Marrakesh, came to their aid and

93. Louise Mirrer, "Representing 'Other' Men: Muslims, Jews, and Masculine Ideals in Medieval Castilian Epic and Ballad," in Medieval Masculinities: Regarding Men in the Middle Ages, ed. Clare A. Lees with Thelma Fenster and Jo Ann McNamara (Minneapolis: University of Minnesota Press, 1994), 169-86. See also Thomas E. Burman, Religious Polemic and the Intellectual History of the Mozarabs, c. 1050-1200 (Leiden: Brill, 1994).

94. Álvaro Soler del Campo, La evolución del armamento medieval en el reino castellano-leonés y Al-Andalus (siglos XII-XIV) (Madrid: Servicio de Publicaciones del E.M.E., 1993), 177-79; and Robert I. Burns, "100,000 Crossbow Bolts for the Crusader King of Aragon," Journal of Medieval Military History 2 (2004): 159-64.

95. Simon Barton and Richard Fletcher, trans., The World of El Cid: Chronicles of the Spanish Reconquest (Manchester: Manchester University Press, 2000), 148-263; and Antonio Maya, Chronica Adefonsi Imperatoris, in Chronica Hispana Saeculi XII, Corpus Christianorum, Continuatio Medievalis 71, ed. Emma Falque, Juan Gil, and Antonio Maya (Turnhout: Brepols, 1990), 109-248. they were joined by very large companies of footsoldiers. ... There were almost thirty thousand horsemen, and the number of foot-soldiers and crossbowmen was beyond reckoning. ... The immense army of the Moabites and Hagarenes went to Toledo.... they began to destroy the vineyards and orchards, but in the city was the Empress Berengaria with a great troop of knights, crossbowmen and foot-soldiers, who stationed themselves on the gates, towers and walls of the city and defended it. ${ }^{96}$ [my emphasis]

This type of straightforward reference to armies of both faiths-each side was said to have horsemen, foot soldiers, and crossbowmen-tells the historical tale from the midtwelfth century on. Crossbows would be uniformly used in the struggles for territory on the Iberian peninsula that have come to be called the "Reconquista," ${ }^{27}$ as at the battles of Alarcos (1195) and Las Navas de Tolosa (1212), when they were employed by both sides; the former was a loss to the Almohads by the armies of Alfonso VIII (d. 1214), the latter a win for the Castilians. ${ }^{98}$ At the same time, throughout Western Christendom, crossbows would be wielded ever more frequently by Christians against their coreligionists,

96. Barton and Fletcher, World of El Cid, 226. Berengaria/ Berenguela (d. 1149) was the first wife of Alfonso VII of LeónCastile (r. 1129-57).

97. On the use of the ideologically freighted term Reconquista to homogenize eight centuries of bellicose interactions between Christians and Muslims in medieval Iberia, see the historiographic analysis by Francisco García Fitz, La reconquista (Granada: Universidad de Granada, 2010). The current lively debate can be followed through the works of Alexander Pierre Bronisch, Reconquista und heiliger Krieg: die Deutung des Krieges im christlichen Spanien von den Westgoten bis ins frühe 12. Jahrhundert (Münster: Aschendorff, 1998), trans. as Reconquista y guerra santa: la concepción de la guerra en la España cristiana desde los visigodos hasta comienzos del siglo XII (Granada: Universidad de Granada, 2006); the review article by Patrick Henriet, "L'idéologie de guerre sainte dans le haut Moyen Âge hispanique," Francia 29, no. 1 (2002): 171-220; and the reply by Bronisch, "Reconquista und heiliger Krieg: eine kurze Entgegnung auf eine Kritik von Patrick Henriet," Francia 31, no. 1 (2004): 199206, trans. as "Reconquista y guerra santa: una breve réplica a una crítica de Patrick Henriet," Anuario de Estudios Medievales 36, no. 2 (2006): 907-15.

98. Ada Bruhn de Hoffmeyer, "Las armas en la historia de la Reconquista," Gladius 18 (1988): 31-101, esp. 48-49; Francisco García Fitz, "La composición de los ejércitos medievales," in La guerra en la Edad Media: XVII Semana de estudios medievales, Nájera, del 31 de julio al 4 de agosto de 2006, ed. Blas Casado Quintanilla and José Ignacio de la Iglesia Duarte (Logroño: Instituto de Estudios Riojanos, 2007), 85-146, at 101, 104, 127. See also J. D. Latham and W. F. Paterson, Saracen Archery: An English Version and Exposition of a Mameluke Work on Archery (ca. A.D. 1368) (London: Holland, 1970), esp. 85-89. 
despite the papal decree. The success of the crossbow in war and sport, together with the mechanical developments that allowed it to be armed from a dignified position, meant that the specific iconography examined here was not long lived. Both the weapon and the warrior wielding it became ubiquitous, as much in later medieval armies as in the secular tales told about them.

But that was later. At the beginning of the twelfth century, there was an undeniable logic to making use of the crossbowman's crouch in church decoration as a way of assimilating and evoking several ideas at once: the initial visual inspiration of Muslim soldiers; the condemning of a powerful weapon that lent itself to ignoble misuse; a shameful display of the genitals that merited the derision of the upright; the familiar Romanesque figure of the squatting, masturbating ape; and the beastly nature of the man who gives in to the temptation of lust, aping the ape. The fact that this iconography appears in such different settings-church interiors, portals, and cloisters-juxtaposed to a wide variety of figural imagery (or none at all, in the case of Saint-Sernin at Toulouse, where it is the only historiated capital on the southwestern wall) shows that we cannot generalize about why it was chosen for these particular churches. Rather, each cathedral or monastic context calls for specific analysis to determine why the new iconography was considered appropriate there. My hope is that this first attempt to comprehend the crouching crossbowmen as a group will stimulate further interest in investigating their individual meaning within particular settings. How do these creatures interact with the other sculptures that surround them? Did they form part of a larger program, or was each complete unto itself?

My reading of these figures-some monstrously attractive, others humiliatingly deformed-recognizes originality in the design of sculptural imagery as a way in which social history was refracted through the prism of iconography. There had been no concrete visual antecedent for the crossbowman before these early twelfth-century naked squatters were created, beyond the borrowed Greek satyrs and Romanesque apes who crouched to masturbate. Rather, the action of cocking the crossbow (the subject of jeers and obscene jokes in real life? ${ }^{99}$ ), by the hands of a despised foe, was captured in sculpture. Anna Comnena had made the crossbow's use a cultural differentiator that identified Western Christians as barbarians, while its gesture came to be embodied in Romanesque sculpture through these same Christians' contact with Muslims. As the weapon was taken up for common use against coreligionists, however, the humiliating critique intended by their inclusion in sacred settings became ineffectual. Instead of serving as a marker of difference, by the later twelfth century the crossbow was eagerly embraced and its original "otherness" dismissed. For this reason the image ceased to be reproduced, and its meaning was lost for future generations of both churchgoers and scholars. The crouching crossbowman's failure to thrive, in contrast to Luxuria's presence throughout the twelfth century, demonstrates the danger inherent in creating a new iconography based on up-to-theminute social and technological developments: the power of the image could be lost once the gesture on which it depended was no longer so timely.

99. While documenting "real life" is a slippery issue, we can be certain of these jeers by the fifteenth century, when the crossbow came to be an element of farce. Michel Rousse, "Les objets facétieux dans les farces françaises des XVe et XVIe siècle," Bulletin de l'Association d'étude sur l'humanisme, la réforme et la renaissance 7 , no. 1 (1978): 25-30. 